\title{
Vzhled jako kognitivní zkratka v politickém uvažování: Experimentální studie vlivu stereotypů na hodnocení politikư $v$ prostředí se silnou prítomností politických témat ${ }^{1}$
}

\author{
Appearance as a Cognitive Shortcut in Political Judgment: \\ An Experimental Study of the Impact of Stereotypes on Politicians' \\ Evaluation in an Issue-Rich Environment \\ Roman Chytilek, Otto Eibl, Lenka Hrbková, \\ Jozef Zagrapan, Jozef Janovský
}

\begin{abstract}
This experiment follows studies researching the impact of candidates' physical appearance on voter decision-making, and adapts this agenda to the Czech context. Candidates' appearance is a good source of stereotypes which can work as an important information source used by voters to make an election choice. Unlike most of the available studies, this experiment stresses not only the visual aspect of the candidates, but also focuses extensively on their positions on political issues. The effects of stereotypes derived from the ethnicity, age and weight of candidates is tested in an information-rich political environment. The results show that the key factors in voters' decision-making are mainly issues, not the candidate's appearance. In the context of elections characterised by the strong presence of political issues, the space for stereotypes derived from candidates' appearance is very limited.
\end{abstract}

KEYWORDS Appearance, stereotypes, political judgment, experimental political science, electability of candidates

\section{Úvod}

Rozhodování a uvažování občanů o politických záležitostech je dlouhodobě předmětem zájmu politických vědců. Po několik desetiletí věnovali politologové v rámci úsilí o větší porozumění tomu, jakým zpo̊sobem tyto procesy fungují, pozornost celé řadě významných

Sociální studia. Katedra sociologie FSS MU, 1/2014. S. 81-108. ISSN 1214-813X.

1 Tento text vznikl v rámci grantového projektu „Experimentální výzkum volebního chování a rozhodování ve vysoce personalizovaných volbách“ (kód P408/GA13-20548S). Jeho průběžná verze byla prezentována na Konferenci výzkumné skupiny pro politickou komunikaci Mezinárodní politologické asociace (IPSA RC 22) v Granadě v záŕí 2013. Autoři děkují oběma anonymním recenzentům za poznámky, které jednoznačně vylepšily kvalitu textu, a dále Bohuslavu Binkovi za účinnou pomoc s konstrukcí kontinua politických pozic v oblasti energetické politiky. 
proměnných, jež do těchto procesů vstupují. Individuální politické uvažování a rozhodování voličů však i dnes zůstává do velké míry spíše černou skř́ínkou. Jedná se totiž o velice komplexní proces, do kterého zasahuje velké množství vstupů, jejichž alespoň zdánlivě konečný výčet není $\mathrm{v}$ rámci současného stavu poznání politického rozhodování $\mathrm{k}$ dispozici.

Ve snaze o bližší uchopení této rozsáhlé politologické problematiky lze sledovat částečný přesun pozornosti od témat spojených s tradičním paradigmatem racionální volby, jako je pozice kandidátů či stran, $\mathrm{k}$ politickým tématům, hodnocení předchozího výkonu politických aktérů atd., k méně předvídatelným faktorům, jež však mohou hrát neméně důležitou roli a které se zároveň mohou často dosti vzdalovat od normativních představ o správném chodu demokratického politického procesu. Tím postupně dochází $\mathrm{k}$ určitému zrovnoprávnění obou př́stupů $\mathrm{k}$ problematice politického rozhodování a volebního chování. Zatímco v severoamerické i západoevropské výzkumné obci jsou hodnocení a charakteristiky politiků považovány za významný aspekt volebního chování, v české politologii se $\mathrm{s}$ tímto tématem setkáváme pouze výjimečně (nap̌r. Bernard 2012). Dostupná literatura vycházející z výzkumu stereotypů souvisejících se vzhledem kandidátů do značné míry poukazuje na význam právě takových stereotypů a jejich nezanedbatelný vliv na politické rozhodování voličů (např. Todorov a kol. 2005; Fershtman a kol. 2005; Rödin a Özcan 2009; Mattes 2010; Castillo a Petrie 2010; Schubert a kol. 2011).

Tento text navazuje na současný stav poznání o vlivu vzhledu kandidáta na jeho potenciál uspět ve volbách a rozšiřuje jej o značně opomíjenou dimenzi, kterou jsou politické postoje kandidátů. Dosavadní stav poznání, vycházející převážně z anglosaského výzkumného prostředí, totiž při posuzování vlivu vzhledu politických osobností nezohledňuje významný faktor volební soutěže, kterým jsou politická témata a postoje kandidátů k nim. Výzkumné designy převážně zdůrazňují fyzický vzhled a související stereotypy, zatímco tradičně klíčová proměnná - umístění kandidáta $\mathrm{v}$ politickém prostoru - je odsunuta výrazně do pozadí. Tímto náš výzkum zaplňuje jedno poměrně překvapivé bílé místo ve výzkumu působení vzhledu kandidátů na rozhodování voličů. Jeho základní otázkou je to, jak se hodnocení osobností kandidátů projeví $\mathrm{v}$ ochotě daného kandidáta volit $\mathrm{v}$ kontextu silné př́tomnosti politických témat. Politická témata jsou totiž dle našeho názoru stále velmi důležitou součástí politické soutěže především v moderních multipartismech, ve kterých jako hlavní političtí aktéři dominují politické strany, a nikoliv jednotliví kandidáti. Na následujících stránkách pak ukážeme, že osobnosti kandidátů i politická témata jsou koncepty navzájem natolik úzce propojené, že jejich vztah a význam by měly být v dalším výzkumu více reflektovány.

\section{Teoretická východiska}

Kandidát a jeho reprezentace ve voličově mysli

Osobnosti politických kandidátů a jejich hodnocení mohou voličům pomoci ke snadnější orientaci v politickém prostředí a do určité míry tak kompenzovat limity informované racionální volby, jež je velmi často $\mathrm{v}$ komplexním informačním prostředí politického života kognitivně př́liš náročná. Fakt, že voliči jsou v určitém smyslu různě kompetentní $\mathrm{k}$ tomu, aby činili kvalifikovanou volbu, je dlouhodobě znám. Nedostatečný zájem a nízká informovanost voličů o politice jsou také často chápány jako určitý normativní demokratický deficit. 
Důležité však je to, jakým způsobem se voliči i za těchto podmínek v politické realitě orientují a rozhodují, protože ve skutečnosti činí celou řadu rozhodnutí, včetně rozhodnutí volebních. Jedním z nástrojů, které jim toto umožňují, jsou heuristiky, tedy jakési kognitivní zkratky, jež umožňují rozhodování v komplexních informačních situacích bez znalosti důležitých faktů a informací: ,„...lidé mohou dostatečně informovaně uvažovat o politice i bez velkého objemu znalostí" (Sniderman, Brody a Tetlock 1991: 19; srov. Lupia 1994; Popkin 1991).

Tyto heuristiky, umožňující voličům efektivní rozhodování v informačně př́liš náročném prostředí, mohou mít celou řadu podob. Jako zkratka volebního rozhodování může působit např́ílad stranická identifikace, hodnotová orientace (popřípadě ideologie ${ }^{2}$ ), politický endorsement kandidáta ze strany respektované osobnosti nebo skupiny, předvolební průzkumy voličských preferencí nebo hodnocení výkonu minulé vlády (například Popkin 1991; Lau a Redlawsk 2001; Lefevere 2011; McGraw 2000: 345-346). Jednou z často zmiňovaných rozhodovacích zkratek je také hodnocení osobností politiků. Lau a Redlawsk (2001) považují za nejvýznamnější kognitivní zkratku prímo vzhled kandidáta, a to proto, že její působnost není omezena pouze na politickou realitu, ale dotýká se všech aspektů sociálního života jednotlivce. Jediný pohled na kandidáta přitom poskytuje velké množství informací včetně pohlaví, rasy, věku a úrovně určité obecné sympatičnosti. Tyto informace okamžitě aktivují související stereotypy. ${ }^{3}$ Vizuální aspekt kandidáta také vyvolává u voličů emoce, jež mají - za určitých okolností, které jsou spojeny s množstvím dalších informací, jež má volič $\mathrm{k}$ dispozici, a s charakterem a komplexností situace, ve které má k rozhodnutí dojít významný vliv na to, jak bude dále hodnocen. $\mathrm{V}$ zásadě tedy můžeme říct, že poznávání a evaluace kandidátů voliči probíhá na základě hodnocení toho, jak daný kandidát vypadá, jak se chová (popřípadě choval v minulosti) a jak voliči toto jednání interpretují (srov. Malá 2013: 11). Mehrabian (1971: 15-16) dodává, že nonverbální složka komunikace kandidátů může mít vliv nejen na to, jak je kandidát vnímán a přijímán, ale i na typ voličů, které svým chováním oslovuje. Obličej kandidáta slouží jako významný zdroj informací, z něhož voliči dokáží vyvozovat řadu závěrů. Jak ukazují Todorov a kol. (2005) a Mattes a kol. (2010) v experimentálních studích, voliči dokáží pouze na základě vizuálního stimulu přisuzovat kandidátům určité charakteristiky: kromě kompetence pro výkon úřadu (Todorov 2005) také atraktivitu, zdroj potenciálního fyzického ohrožení směrem k voličům a zákeřnost (Mattes

2 V této souvislosti je zajímavé tvrzení, se kterým přichází Brady a Sniderman (1985). Ti říkají, že ačkoliv voliči nemusí plně rozumět obsahu abstraktních pojmů, jako jsou liberalismus a konzervatismus, jsou stále schopní provádět odhady konkrétních liberálních či konzervativních politik na základě informací, kterými v dané chvíli disponují. Pokud tak volič má informaci např́íklad o postoji kandidáta či strany k určitému tématu, je schopný na základě této informace odhadovat pozice i v dalších tématech.

3 V zásadě jde o to, že máme tendenci přisuzovat člověku vlastnosti na základě vlastností jiných (například tlustý člověk se jeví jako líný) a často bipolárních (inteligentní či neinteligentní člověk) (srov. Malá 2013: 12) - a to bez ohledu na individuální odlišnosti jedinců. Stereotypy tak zjednodušují (a zkreslují) vnímání světa, který nás obklopuje, a mezi výzkumníky panuje shoda v tom, že mají poměrně značný vliv na volební proces, byt' intenzita, se kterou se projeví, je různá a odvíjí se např́klad od množství informací, jimiž kandidát disponuje, popř́ípadě od témat, o kterých kandidát mluví (Sapiro 1981-1982; Huddy a Terkildsen 1993; Kahn 1996; Iyengar a kol. 1997). 
2010). Tyto odvozené charakteristiky pak spolehlivě dokáží predikovat skutečné výsledky volebních soutěží. Například kandidáti, kteří byli označeni jako fyzická hrozba, v $65 \%$ případů ve volbách prohráli. ${ }^{4}$

\section{Stereotyp fyzického vzhledu kandidátů jako zkratka vedoucí k volbě?}

Vzhled kandidáta je poměrně obecný pojem, do kterého lze zařadit celou řadu konkrétních charakteristik kandidáta, jako jsou např́klad gender, rasa (popřípadě etnicita), věk či obecné fyzické charakteristiky jedince (např́klad tělesná váha). Vliv a přítomnost stereotypů, které se $\mathrm{k}$ těmto charakteristikám váží, se projevil (byt' s různou intenzitou) v četných studiích. ${ }^{5}$ Mezi výzkumníky panuje do značné míry shoda $v$ tom, že vizuální stimuly ovlivňují naše vnímání světa - at' už se jedná o hodnocení kandidátů, událostí či témat (Gilliam a Iyengar 2000; Graber 1987, 1990; Nisbett a Ross 1980; Palvio 1991). Vzhled kandidáta navíc může posilovat (či oslabovat) jeho tzv. volitelnost (electability), tedy potenciál získat hlasy voličů a zvítězit ve volební soutěži. Existují např́íklad empirické důkazy, že fyzická atraktivita zvyšuje šance kandidátek-žen na zvolení v důsledku pozitivních stereotypů spojených s atraktivitou (Sigelman, Sigelman a Fowler 1987). V souvislosti s výzkumem vlivu pohlaví na volbu celá řada experimentů (Huddy a Terkildsen 1993; Kahn 1996; Sapiro 1982; Matland 1994;

4 Typickým př́kladem toho, jak vzhled kandidáta ovlivňuje vnímání voličů, byla první televizní debata prezidentských kandidátů v USA z roku 1960. V této debatě proti sobě stáli John F. Kennedy a Richard Nixon. Za vítěze televizní debaty diváci v průzkumu provedeném společností pro výzkum trhu Sindlinger\&Company označili atraktivního a opáleného Kennedyho, zatímco pobledlý potící se Nixon u televizních diváků neobstál. Debata byla zároveň vysílána i rozhlasem. Právě posluchači rozhlasu, kteří nebyli pod dojmem vizuálního aspektu kandidátů, za vítěze debaty označili naopak Nixona. Metodologie zmíněného průzkumu není sice zcela přesvědčivá v důsledku absence informací o velikosti a lokaci vzorku, poměrně významnému časovému odstupu průzkumu od samotné debaty atd., přesto lze považovat efekt vizuálního působení kandidátů za platný, což dokládá např́íklad experimentální výzkum J. Druckmana (2003), jenž retestoval na vzorku diváků a posluchačů rozdíl ve vnímání Nixona a Kennedyho v této debatě v závislosti na přítomnosti nebo absenci vizuálního stimulu.

5 Je ale třeba připomenout, že ne všechny stereotypy jsou zkoumány se stejnou četností a intenzitou. A tak zatímco genderu či rase kandidátů jsou věnovány desítky studií, věk kandidátů nebo třeba jejich váha jsou zkoumány v souvislosti s volebním chováním spíše sporadicky - a to i přesto, že jde o poměrně silné heuristiky, ke kterým se váží četné stereotypy (například obézní lidé jsou vnímáni jako líní, nezodpovědní a hloupí [O’Brien, Latner, Ebneter a Hunter 2012: 1]), staří lidé jako nerozhodní a lehko manipulovatelní. Výjimku představuje studie o (nad)váze kandidátů, kterou provedli Miller a Lundgren (2010). Z výsledků studie plyne, že za nadváhu jsou „trestány“ zejména ženy, naopak obézní muži byli hodnoceni subjekty dokonce pozitivněji než kandidáti bez nadváhy. Tento závěr je pak v rozporu s jinými - v nepolitickém prostředí prováděnými - výzkumy (O’Brien, Latner, Ebneter a Hunter 2012: 3). Roli věku kandidáta se věnovali v USA Sigelman a Sigelman (1982). Z jejich experimentální studie plyne, že právě věk měl na volební rozhodnutí účastníků experimentu významnější dopad než rasa či pohlaví politických kandidátů. Viditelně starší kandidát byl svým věkem navíc systematicky znevýhodňován. 
Kahn 1993, 1996; Aalberg a Jenssen 2007 a další) ${ }^{6}$ ukázala, že existuje sada „typicky mužských“ a „typicky ženských“ témat, vlastností a způsobů vedení kampaně, ${ }^{7}$ které jsou od kandidátů očekávány. $\mathrm{V}$ závislosti na tématu, o kterém se rozhodovalo, se pak tyto vlastnosti pozitivně nebo negativně promítaly do hodnocení kandidátů.

To, že fyzický vzhled ovlivňuje vnímání kandidáta ze strany voličů, kteří si na tomto základě vytváŕí jasnou představu o jeho charakteru a schopnostech, tvrdí i Rosenberg a kol. (1986). Nonverbální faktory jako vzhled a styl kandidáta působí také př́mo na volební rozhodnutí. Ve své experimentální studii testovali vliv kandidáta za kontroly jeho ideologické orientace a postojů $\mathrm{k}$ vybraným politickým tématům. $Z$ výsledků studie vyplývá, že vzhled kandidáta poskytuje voličům obraz o vhodnosti kandidáta pro danou volenou pozici a také obecně o charakteru daného kandidáta (o vlastnostech jako jsou kompetence a integrita, vůdcovská schopnost, atraktivita atd.). Vizuální aspekt kandidáta tedy může voličům zprostředkovat řadu politicky relevantních informací. Kromě hodnocení kandidátů působí vzhled politiků také na samotné volební rozhodnutí, jelikož atraktivnější kandidáti dosahovali v rámci tohoto experimentálního výzkumu systematicky lepších volebních výsledků. Ideologická orientace a politické postoje kandidátů pritom v rámci této studie nevykazují žádný intervenující vliv ve vztahu ke vzhledu kandidáta.

Další studie pak ukázaly, že pozitivněji jsou přijímáni kandidáti, se kterými subjekty sdílí některé charakteristiky (typicky rasu či prř́slušnost $\mathrm{k}$ etnické skupině). Např́ílad Bertrand a kol. (2005) zjistili, že v testu implicitních asociací byly hodnoceny fotografie tvárí Afroameričanů hưře než tváře bělochů. Další experimenty (Fershtman a kol. 2005; Castillo a Petrie 2010; Rödin a Özcan 2009) pak ukázaly, že se tyto stereotypy promítají i do míry důvěry, se kterou $\mathrm{k}$ daným osobám respondenti přistupují, a ochoty s nimi spolupracovat. V kontextu naší studie je pak třeba zdůraznit, že síla stereotypu se v tomto př́ípadě opět snižovala s množstvím informací, které byly o objektech poskytnuty. K opačnému závěru o vlivu množství dostupných informací došli Matsubayashi a Ueda (2011). Z jejich výzkumu plyne, že bílí voliči s vyšším socioekonomickým statusem, většími politickými znalostmi a více informacemi o kandidátech spíše nevolí Demokratickou stranu (v USA), pokud je kandidát černé pleti. V př́ípadě, že bílí voliči neodpovídají tomuto profilu, je pro ně rasa kandidáta nedůležitá. Takový závěr je však ojedinělý.

Omezený vliv vzhledu kandidáta pak zaznamenali Wyer a kol. (1991). Z výsledků však vyplývá významný efekt vzhledu kandidáta pouze za předpokladu nesouladu mezi politickými postoji voliče a postoji kandidáta. Vnímání vzhledu nehraje dle autorů $\mathrm{v}$ rámci volebního rozhodování významnou roli, pokud se volič nachází v ideologické blízkosti kandidáta a souhlasí s jeho politickými postoji. Postojová blízkost tak eliminuje vliv fyzického vzhledu na to, jak voliči kandidáty hodnotí. Prostorové usporádání postojů kandidátů a jejich voličů

6 Gordon, Shafie a Crigler (2003) v této souvislosti zjistili, že v okamžiku, kdy volič disponuje více informacemi, nebo kdy žena-kandidátka zmíní mužské téma, vliv stereotypu slábne, popř́ípadě mizí. Kandidáti pak mají v myslích voličů „stejnou výchozí pozici“.

7 Neústupnost, agresivita, nezávislost a ekonomická témata na straně mužů a čestnost, citlivost, soucitnost a sociální témata na straně žen. 
zde představují na rozdíl od výzkumu Rosenberga a kolegů významný faktor zprostředkující vliv vizuálního působení kandidátů.

Problematiku dopadu vzhledu politických osobností na voliče dále rozvíjí Schubert a kol. (2011), kteří na základě poznatků evoluční psychologie a kognitivní neurovědy vycházejí z přesvědčení, že lidé mají přirozenou tendenci k preferenci některých typů fyzického vzhledu před jinými. Zároveň voliči přiřazují kandidátům povahové rysy a schopnosti právě na základě vizuálního dojmu. Stereotypy o lídrech tak reflektují tyto preferenční predispozice a ovlivňují úsudky voličů o vhodnosti a volitelnosti jednotlivých kandidátů. Jejich data potvrzují, že za nejvíce volitelné kandidáty voliči považují ty, jejichž vzhled je zároveň hodnocen nejpříznivěji. V souvislosti s politickými postoji jsou však jejich výsledky v určitém protikladu k výše zmíněné Wyerově studii, jelikož všichni kandidáti s kladně hodnoceným vzhledem, bez ohledu na ideologickou vzdálenost od voliče, získali volební převahu nad ostatními kandidáty s méně příznivě hodnoceným fyzickým zevnějškem. Schubert a kol. se na rozdíl od výše citovaných výzkumů snaží dále o hlubší vysvětlení kauzálního mechanismu spojujícího vzhled kandidáta a jeho volitelnost. Na voliče podle jejich předpokladů působí tzv. asimilační efekt, jehož působením získávají atraktivnější kandidáti lepší hodnocení a volební výsledky. Asimilační efekt v politickém uvažování nastává v situaci, kdy volič vnímá pozice strany nebo kandidáta jako podobnější vlastním postojům, než ve skutečnosti jsou. Signifikantní asimilační efekt se vyskytoval právě pouze u atraktivních kandidátů, u nichž docházelo $\mathrm{k}$ většímu zkreslení ve vnímání jejich ideologických pozic. Ze závěrů tohoto výzkumu vyplývá, že politici, jejichž vzhled a styl chování splňují standardní představu volitelnosti, pak mají jednodušší pozici pro získávání finančních prostředků, mediální pozornosti a podpory. Naopak ti, kteří nenaplňují standardní stereotyp, nedokáží získat dostatečnou veřejnou pozornost pro své politické postoje. Ve volbách s více kandidáty pak voliči upřednostňují mezi ideově podobnými osobnostmi tu, jejíž vzhled více odpovídá standardnímu stereotypu.

Některé výzkumy se zaměřují také na kontextuální faktory, jež mohou ovlivnit roli vzhledu v tom, jak lidé posuzují politické kandidáty. Např́klad Banducci a kol. (2003) zjistili, že vzhled je jako kognitivní zkratka více využíván v komplexnějších volebních situacích - tedy pokud volič musí vybírat $\mathrm{z}$ většího počtu kandidátu - a také v podmínkách kognitivně náročnějšího volebního systému (ve zmíněné studii se jedná o systém jednoho přenosného hlasu). Zároveň autoři kladou důraz na to, že tato heuristika vzhledu platí především ve volbách s nízkou úrovní informací, ve kterých fotografie kandidáta představuje zcela zásadní zdroj informací potřebných k posuzování jednotlivých kandidátů (srov. s výsledky experimentu, který provedli Barret a Barrington 2005). Stereotypní reakce na tyto informace potom může ovlivňovat volební výsledky, především pak postrádají-li voliči relevantnější informace o jednotlivých kandidátech.

Výsledky studie Banducci a kol. pak do značné míry korespondují se závěry experimentální studie, kterou v roce 1992 provedli Riggle a kol. Na základě experimentu s fiktivními politickými kandidáty autoři zjistili, že stereotypům subjekty podléhají zejména $\mathrm{v}$ př́padě, kdy nemají $\mathrm{k}$ dispozici informace o politických pozicích kandidátů a kdy se rozhodovací situace stává složitější (musí si vybírat mezi různými kandidáty různých stran a k dispozici mají záznamy o jejich hlasování o různých politických tématech). Zajímavý je i další z jejich 
závěrů - s tím, jak se zvyšuje komplexita prostředí, ve kterém rozhodnutí probíhá, roste a klesá role různých heuristik: Zatímco v prípadě posuzování fotografíi bez dalších informací hrají roli stereotypy týkající se vzhledu, v případě posuzování jednoho kandidáta s informacemi o stranické př́slušnosti a záznamem o jeho předchozích hlasováních hraje roli blízkost k politickým tématům - nikoliv stranická př́slušnost (!) -, v okamžiku, kdy má volič hodnotit více kandidátů z různých stran (a má $\mathrm{k}$ dispozici informaci o hlasování), hraje roli stranická př́slušnost, nikoliv blízkost.

Můžeme tedy ř́ci, že jakmile mají voliči k dispozici informaci o stranické př́slušnosti a politických postojích kandidáta, nemá již fyzický vzhled na jeho ohodnocení významný vliv. Postoje kandidátů $\mathrm{k}$ politickým tématům totiž představují přímý indikátor míry, do jaké je kandidát podobný voličům co do sociálních hodnot a politických názorů. Je evidentní, že vztah mezi vzhledem kandidáta a jeho politickými postoji jakožto faktory působícími na volební rozhodování voličů je stále poněkud nejasný vzhledem k poměrně protichůdným výsledkům výše zmiňovaných studií.

\section{Vzhled vs. informace - hledání chybějícího článku}

Náš výzkumný zájem se - na základě výše nastíněného dosavadního stavu zkoumání zaměřuje právě na problematiku nejasného vztahu mezi tím, jak voliči kandidáty hodnotí na základě toho, jak vypadají, a postoji voliče k politickým a ideologickým pozicím jednotlivých kandidátů. Zkoumáme tedy, zda vzhled kandidátů hraje roli v situacích (poprrípadě v politických systémech obecně), které jsou založeny na silné přítomnosti politických témat.

Design experimentálních studií Wyera (1991) a zejména Schuberta a jeho kolegů (2011) si z hlediska interní validity zkoumání způsobu, jakým stereotypy moderují rozhodování voličů $\mathrm{v}$ prostředí, v němž jsou př́tomna i politická témata, nemůže podle našeho názoru nárokovat univerzální platnost. Dobře reprezentuje situace, $v$ nichž jsou zároveň naplněny tři podmínky: 1 . vysoká personalizace voleb, 2 . nízká stranická identifikace voličủ a/nebo situace vnitrostranických voleb a 3. předpoklad, že kandidáti „předcházeji“ před politickými tématy. Subjekty v experimentu Schuberta a spol. např́íklad nejdřive deklarovaly své sympatie ke kandidátům na základě sledování krátkých, z hlediska střihu standardizovaných (dvacetisekundových) klipů z televizní debaty, a teprve poté byly podrobněji informovány o jejich politických postojích. Vzhled kandidáta jako rozhodovací zkratka a s ní související asimilační efekt tak představují nadějný teoretický rámec například pro americké primární volby, př́padně pro volby $\mathrm{v}$ zemích $\mathrm{s}$ organizačně velmi slabými politickými stranami a volbami, v nichž (typicky $\mathrm{v}$ jednomandátových obvodech) vystupují do popředí kandidáti, či pro personalizované volby na substátní úrovni. Pro ostatní př́pady je ovšem vliv vzhledu kandidáta jako rozhodovací zkratky samotným designem experimentu zjevně nadhodnocen.

Evropské multipartismy s celostátně organizovanými a alespoň relativně nominálně stabilními, centralizovanými a disciplinovanými politickými stranami, ale např́klad i americké prezidentské volby lze spíše vnímat skrze výkladový rámec, který nabízí Riggle a kol. (1992). Míra personalizace i stranické identifikace $\mathrm{v}$ nich $\mathrm{v}$ jednotlivých zemích kolísá. Zejména v nich však není naplněna třetí podmínka - primát kandidátů před politickými tématy. Nelze je totiž jednoznačně považovat za volby s nízkou úrovní informace. Ǩada výzkumů (Enelow 
a Hinich 1984; Alvarez a Franklin 1994; Alvarez 1997; Alvarez a Brehm 2002) ukazuje, že voliči chápou politické strany mj. i jako nositele politické informace a snaží se způsobem a měrou související s jejich politickou sofistikovaností získat informace o jejich politice. V př́ípadě, že jimi o některé straně nedisponují, klesá šance, že ji budou volit (Alvarez 1997: 109). Toto zjištění prritom nijak neimplikuje, že informace všech voličů o politice strany je víceméně shodná, přesná a aktuální. Podle Alvareze s Brehmem jde o sebeposilující se proces, v němž nejvýznamnější roli hrají informace získané voliči nejdříve. Ty pak zakládají predispozici k selektivní percepci informací následujících.

Kandidáti tak operují $\mathrm{v}$ prostředí poskytujícím pouze omezený prostor pro inovace a akcentování vlastních politických pozic. ${ }^{8}$ Sánchez-Cuenca (2007) např́klad ukazuje, že v případě, že se strana či její kandidát v některém tématu příliš odchýlí od svých původních pozic nebo ideologického profilu, nemusí ji volič podpořit, i když nově reprezentuje v tomto tématu jeho ideální politickou preferenci, nebot' je v rozporu s jeho zažitou představou strany. Adams a kol. (2011) v jedné z mála studií zkoumajících vnímání změny politiky voliči pak zase konstatují, že voliči mají dokonce problém změnu politické pozice vưbec zaznamenat. Typicky tak vstupují kandidáti do politické soutěže, v níž 1) jsou dlouhodobě a významně přítomna některá politická témata (jako jsou ekonomika, sociální věci či vyrovnání s minulostí), s 2) omezenou možností zaujímat v nich inovativní postoje, přičemž 3) voliči vždy disponují určitou (nenulovou) mírou informace o politice strany. Rozhodovací zkratky založené na vzhledu kandidáta zde nemají exkluzivní pozici jako ve volbách s nízkou úrovní informace a lze předpokládat jejich menší vliv.

Náš experimentální design se proto snaží zaplnit výše naznačené bílé místo. Vliv stereotypů zkoumáme v prostředí se silnou přítomností pro subjekty různě palčivých politických témat, ve kterém navíc zároveň existuje vysoká míra informovanosti voličů o pozicích kandidátů. Ty jsou pro každého kandidáta dynamicky generovány (popisu procedury se věnuje následující oddíl) tak, aby umožňovaly různou míru identifikace subjektu s každým z kandidátů. Na základě představené teorie formulujeme následující hypotézy:

H1: V soutěži se silnou přítomností politických témat nemají stereotypní kritéria vliv na hodnocení kandidáta (Riggle a kol. 1992).

V této hypotéze tedy předpokládáme, že silná informovanost voličů o politických pozicích kandidátů potlačuje možnost využití stereotypů jako kognitivní zkratky.

H1a: Míra souhlasu s politickými pozicemi kandidátů neovlivňuje ve volbách s vysokou informovaností voličů to, jak jsou voliči ovlivněni stereotypními kritérii při hodnocení kandidátů.

Pomocí hypotézy H1a testujeme předpoklad, že stereotypní kritéria působí stejně pro kandidáty, s jejichž politickými pozicemi je subjekt ztotožněn, jako pro kandidáty zastávající

8 Naše argumentace se v tomto textu nevěnuje dalším faktorům, které podporují stabilitu politických pozic. Meyer (2013) za nejdůležitější považuje vnitrostranické procesy. 
pozice výrazně odlišné od pozic voliče. Vzdálené kandidáty může volič hodnotit hůře než kandidáty blízké, avšak tento rozdíl nebude ani zčásti vysvětlitelný komponentou založenou na stereotypním rozhodování.

H2: Subjektivní vnímání významu témat v politické soutěži ovlivňuje to, jak jsou voliči ovlivněni stereotypními kritérii při hodnocení kandidátů.

Kromě dvou předchozích teoretických hypotéz formulujeme ještě další, beroucí v potaz subjektivní důležitost témat. Náš experimentální design vybavuje subjekty pro hodnocení kandidátů pouze dvěma druhy informací: vzhledem kandidáta a jeho politickými pozicemi v pěti politických tématech, zatímco ostatní (pohlaví, stranická př́slušnost, předchozí politická historie) drží konstantní. Subjektivní palčivost témat může ovlivnit, jaký význam přikládají participanti každému z obou druhů informací. Subjekty, které vnímají témata jako pro ně málo důležitá, mohou více inklinovat $\mathrm{k}$ tomu, aby využívaly pro hodnocení kandidáta i stereotypní informace související s jeho vzhledem.

\section{Experimentální procedura}

Experiment se uskutečnil v počítačových učebnách Fakulty sociálních studií MU v Brně. Na experimentální sezení jsme pozvali 201 náhodně vybraných studentů Masarykovy univerzity z databáze (vytvořené a spravované pomocí programu ORSEE), do které se zájemci o účast na experimentech mohli přihlásit $\mathrm{v}$ průběhu roku 2012. Celkově se $\mathrm{k}$ experimentu konanému 30. 10. 2012 zaregistrovalo 98 studentů a reálně se dostavila skupina $87 \mathrm{z}$ nich (48 žen, 39 mužů). Účast na experimentu byla subjektům finančně kompenzována, experimentální sezení trvalo méně než 60 minut.

Participanti byli náhodně přiřazeni $\mathrm{k}$ experimentálním podmínkám a po př́chodu do laboratoří - počítačových učeben - byli individuálně usazeni $\mathrm{k}$ počítačům. Před začátkem samotného úkolu účastníci podepsali informovaný souhlas s experimentální procedurou a administrátor, který dohlížel na proces sezení, je seznámil s fungováním dotazníku vytvořeného v programu Qualtrics. Administrátoři, podobně jako participanti, nebyli seznámeni $\mathrm{s}$ účelem experimentu.

V první části jsme zjišt'ovali zájem o politiku a základní demografické údaje. Následně se v dotazníku objevily otázky, které měly zjistit názor účastníků experimentu na pět témat (budoucnost energetické politiky v České republice, další směřování Evropské unie, sociální napětí v některých oblastech České republiky, Václav Klaus v roli prezidenta a legalizace marihuany pro léčebné účely). Participanti měli za úkol vyznačit, kterou pozici $\mathrm{k}$ tématu z pěti možných zastávají. Pozice tvořily škálu - krajní pozice byly ve vzájemném protikladu. Např́ílad $\mathrm{v}$ otázce legalizace marihuany pro léčebné účely jednu z krajních pozic představovalo tvrzení: „Marihuana je droga, protože na ní vzniká závislost. $V$ žádném prípadě by neměla být legalizována, a to ani pro léčebné účely, "zatímco druhou tvrzení: „Marihuana může nahradit řadu jiných léčiv. Jeji účinky na organismus jsou jednoznačně pozitivní, pomáhá rozvijet osobnost člověka. Legalizována by měla být všeobecně a stát by ani neměl kontrolovat trh s ní. "Jednotlivé škály byly vytvořeny za pomoci 
konzultací s experty $\mathrm{v}$ dané oblasti a testovány předvýzkumem, abychom si byli jisti, že vzdálenosti mezi jednotlivými pozicemi jsou přibližně stejné. Vždy tak pozice u všech témat tvořily škálu, kdy dvě pozice byly krajní, dvě méně vyhraněné, ale blížící se $\mathrm{k}$ jedné $\mathrm{z}$ krajních, a jedna pozice byla středová (podrobně viz Př́loha). Společně $\mathrm{s}$ tím na škále od 0 (absolutně nedůležité) do 100 (velmi důležité) subjekty označovaly důležitost každého tématu pro ně osobně.

Ve druhé části participanti hodnotili různé (fiktivní) kandidáty, jejichž profil jsme vytvořili pro účely experimentu. Ti byli participantům představeni jako skuteční neúspěšní kandidáti $\mathrm{z}$ minulých senátních voleb, společně $\mathrm{s}$ informací, že záměrně nezmiňujeme jejich jména ani politickou př́slušnost a uvádíme pouze jejich program. Tato informace, v souladu $\mathrm{s}$ výzkumným záměrem experimentu, sloužila $\mathrm{k}$ tomu, abychom neupozorňovali na odlišnost kandidátů a logicky abychom neprozrazovali účel experimentu. Participanti si podle instrukcí měli přečíst pozice kandidátů $\mathrm{k}$ pěti tématům a následně byli vyzváni, aby kandidáty ohodnotili.

Vzhledem k tomu, že naším cílem bylo zjistit vliv vzhledu a vzdálenosti kandidáta a subjektů v politických tématech na jeho hodnocení, byli participanti nejprve náhodně rozděleni do tř́ skupin. Každá skupina měla za úkol hodnotit tři kandidáty. Dva kandidáti byli pro každou skupinu vždy stejní a na základě pilotní studie byl jejich vzhled hodnocen jako neutrální. Rozdíl mezi skupinami spočíval $\mathrm{v}$ třetím kandidátovi. V první skupině se jeden z kandidátů lišil od zmíněných dvou rasou, ve druhé fyzickými predispozicemi a ve třetí věkem. Všechny fotografie pocházely z fotobanky, fotografie ,jiných“ kandidátů (až na kandidáta, který se lišil věkem) byly pro účely experimentu upravené grafikem. Vzhled všech ,jiných“ kandidátů jsme testovali v pilotní studii, abychom se ujistili, že kandidáti dostatečně reprezentují odlišnost, kterou jsme chtěli použít ve výzkumu (rasovou, fyzickou, věkovou). Výsledky předvýzkumu naše očekávání potvrdily a společně s tím se také potvrdilo, že žádná jiná charakteristika nepřevažovala nad charakteristikou, kterou jsme označili za primární odlišnost od „neutrálních“ kandidátů. To například znamená, že „starší“ kandidát se skutečně lišil od ostatních kandidáti především věkem a až potom možnými jinými charakteristikami.

Obrázek 1: Kandidáti, které hodnotila skupina 1

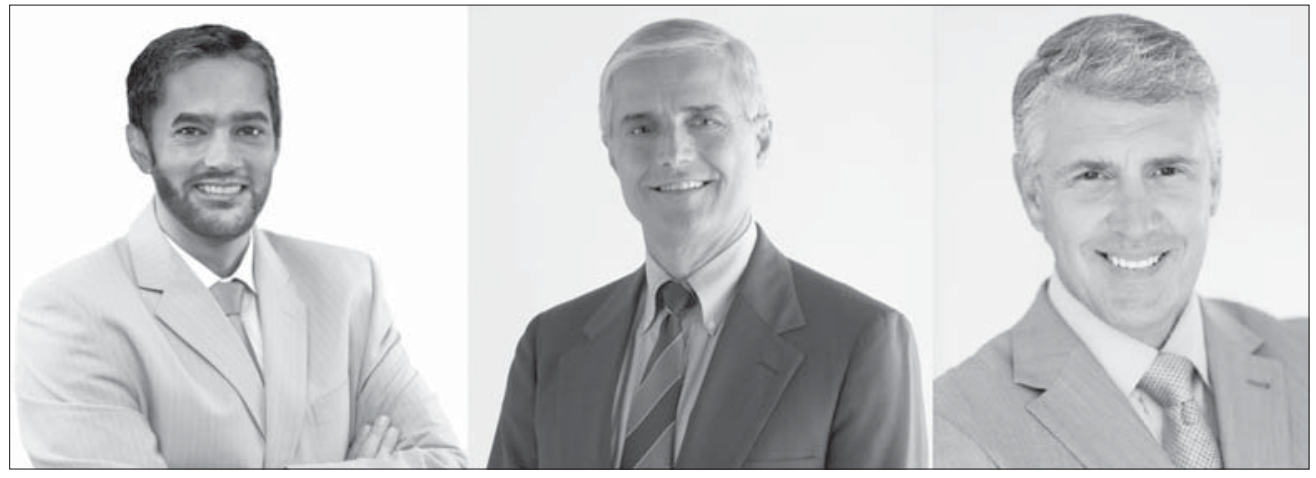


Obrázek 2: Kandidáti, které hodnotila skupina 2

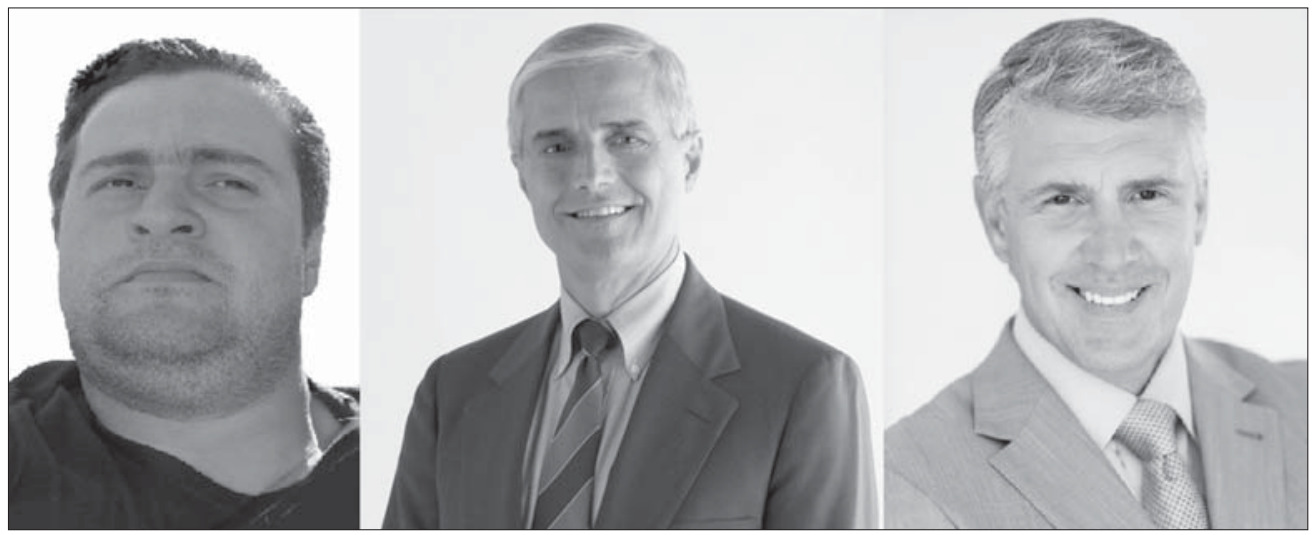

Obrázek 3: Kandidáti, které hodnotila skupina 3

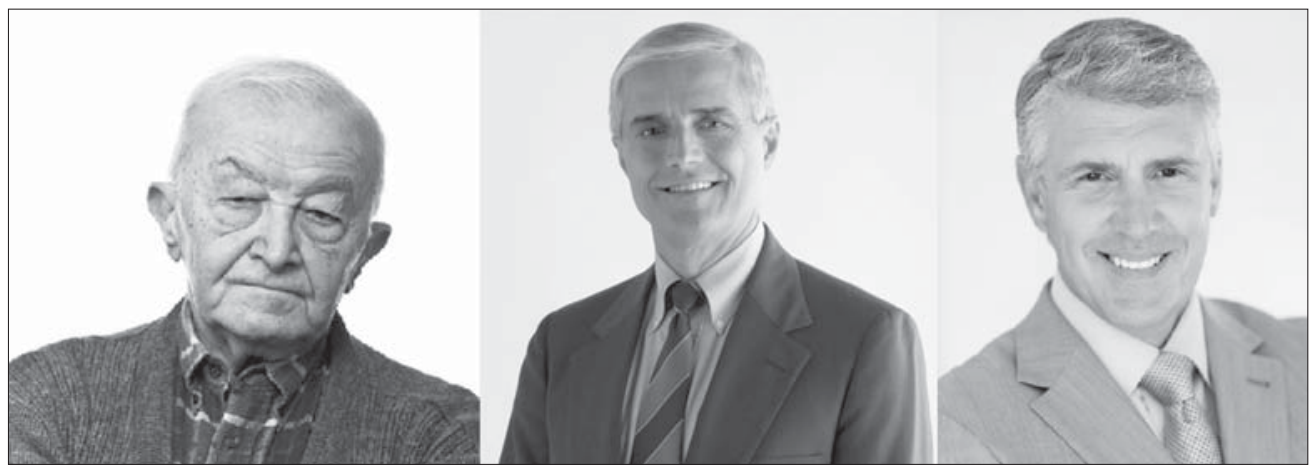

Pozice kandidátů $\mathrm{k}$ tématům byly vytvořeny následovně: na základě odpovědí o pozicích participantů $\mathrm{k}$ různým tématům z první části systém vygeneroval každému z participantů postoje kandidátů ke stejným tématům:

1. Jeden z kandidátů byl participantovi vždy názorově nejblíže. V prrípadě, že si možné pozice k tématům představíme jako pozici 1 (jedna krajní pozice) až 5 (druhá krajní pozice), v momentě, kdy odpovídající označil např́iklad svoji preferovanou pozici ke všem tématům 1, tento kandidát se s ním shodoval u všech témat, až na jedno, kde byl jeho postoj o jednu pozici vzdálenější. $\mathrm{V}$ tomto př́ípadě tak byla kandidátova pozice 2 .

2. Druhý kandidát byl od participanta středně vzdálený, to znamenalo, že ve čtyřech případech byla jeho pozice vzdálená o jednu pozici, v jednom př́ípadě se s účastníkem experimentu shodoval. Opět v prŕpadě, že participant u všech témat preferoval pozici 1, pozice 
druhého kandidáta $\mathrm{k}$ tématům byla ve čtyřech př́padech 2 a v jednom 1. Druhý kandidát se vždy shodoval s participantem v otázce, ve které se první kandidát s participantem neshodoval - u všech participantů se jednalo o pozici k dalšímu směrování Evropské unie.

3. Pozice třetího kandidáta se vždy od participanta lišily o dvě nebo tři pozice. Tento kandidát byl tedy od participanta ideově nejvzdálenější.

Tabulka 1: Pozice kandidátů k tématům v př́padě, že participant zastával vždy pozici 1

\begin{tabular}{|l|c|c|c|c|}
\hline \multirow{2}{*}{ Téma } & \multicolumn{4}{|c|}{ Ideová pozice } \\
\cline { 2 - 5 } & Participant & $\begin{array}{c}\text { Kandidát 1 } \\
\text { (nejbližší) }\end{array}$ & $\begin{array}{c}\text { Kandidát 2 } \\
\text { (středně } \\
\text { vzdálený) }\end{array}$ & $\begin{array}{c}\text { Kandidát 3 } \\
\text { (nejvzdálenějši) }\end{array}$ \\
\hline Vývoj energetické politiky & 1 & 1 & 2 & 4 \\
\hline Směřování Evropské unie & 1 & 2 & 1 & 3 \\
\hline Sociální napětí v ČR & 1 & 1 & 2 & 4 \\
\hline Václav Klaus v roli prezidenta & 1 & 1 & 2 & 4 \\
\hline Legalizace marihuany & 1 & 1 & 2 & 4 \\
\hline
\end{tabular}

Jako konkrétní příklad ilustrující generování pozic kandidátů můžeme opět uvést otázku týkající se legalizace marihuany pro léčebné účely:

1. V první části dotazování participant vyznačil jako svoji preferovanou pozici číslo 1 : „Marihuana je droga, protože na ní vzniká závislost. Vžádném př́padě by neměla být legalizována, a to ani pro léčebné účely.“

2. Na základě této odpovědi se vygeneroval postoj kandidátů $\mathrm{k}$ stejnému tématu. Kandidát 1 se s participantem shodoval a jeho pozice byla následující: „, Marihuana ovlivňnje mysl člověka, pokřivuje jeho vnímání a ve velkém množstvi působi jako jed, je karcinogenní a mnohem horši než cigarety. Uživatelé se na ní stávají závislými. Následky jejího uživání jsou vždy horši než problémy, které se snaží řešit. Neměla by proto být za žádných okolností legalizována, ani pro tzv. léčebné účely. “

3. Kandidát 2 byl od participanta vzdálený jenom o jednu pozici, tedy zastával pozici č́slo dva: „Marihuana využitá pro léčebné účely je mimořádně riskantním prrípravkem. Zatím nebyly zpochybněny výzkumy, podle kterých $v$ delšim horizontu poškozuje pamět i mozek a snižuje mentálni schopnosti. Bez dalšiho výzkumu ji neni možné v medicině podobně jako dalši medikamenty s vedlejšimi účinky využivat, bylo by to i v rozporu s lékařskou etikou. "

4. Kandidát 3 byl od participanta nejvzdálenější, v tomto př́padě o tři pozice, to znamená, že $\mathrm{v}$ otázce legalizace marihuany pro léčebné účely zastával pozici číslo 4: „Využivání 
marihuany v medicíně je v evropských zemích či státech USA, jako je Kalifornie, poměrně běžné, jeji léčebné účinky při vhodném použití byly doloženy četnými studiemi. Jeji legalizací a prodejem v lékárnách na lékařský předpis, stejně jako státní podporou výzkumu jejích účinků, se přibližíme zemím jako Itálie, Švýcarsko či Rakousko. “

Stejný postup platil u všech témat. Pozice jednotlivých kandidátů tak byly vždy dynamicky generovány na základě pozic participanta. Každá skupina participantů byla také rozdělena, opět náhodně, do tří podskupin, aby bylo možné zabývat se i otázkou vlivu stereotypů podle míry ideového souhlasu s kandidátem. V jednom př́padě byl ,jiný“ kandidát participantovi nejbliže, ve druhém středně vzdálený a ve třetím hodně vzdálený.

Obrázek 4: Schéma náhodného rozdělení participantů

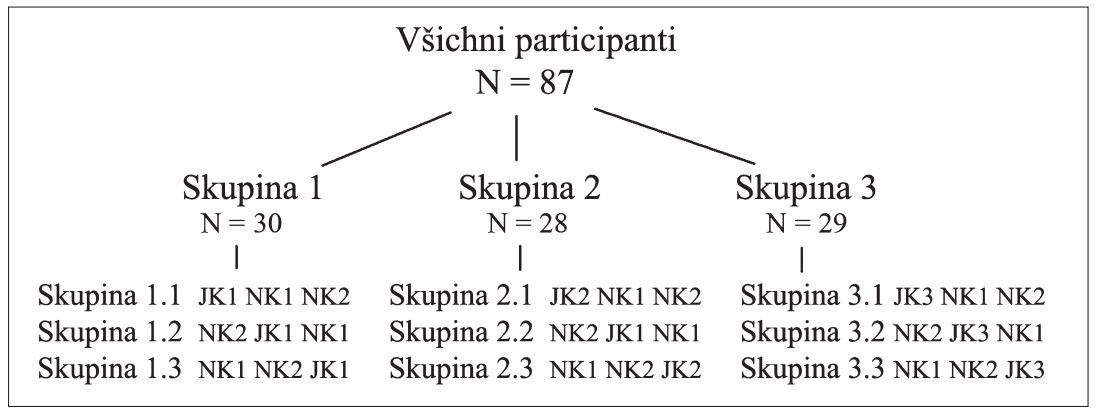

Poznámka: JK - ,jiný“ kandidát, NK - „neutrální“ kandidát.

Celkově jsme v experimentu pracovali s devíti skupinami participantů ( 3 x 3), kdy se jednotlivé skupiny lišily v podobě jednoho z kandidátů a v tom, jak ideově vzdálený (blízko, středně, velmi) byl tento ,jiný“ kandidát. Jak jsme již uvedli, zatímco dva kandidáti - ti, které označujeme jako „neutrální“ - byli vždy stejní, ,jiný“ kandidát se lišil (viz obrázky 1, 2, 3). Jak můžeme vidět na Obrázku $4, v$ každé skupině byl tento kandidát od participantů různě vzdálený. Např́klad zatímco ve Skupině 1.1. systém vygeneroval pozice ,jiného“ kandidáta tak, aby byl participantovi ideově nejbližší, ve Skupině 1.3. byl participantovi nejbližší ,neutrální kandidát 1“ a ,jinýc kandidát nejvzdálenější.

V dotazníku se participantům na obrazovce vždy objevila fotografie kandidáta a pod ní jeho postoje k již zmíněným tématům. Participanti směli přejít na další obrazovku až po určitém časovém intervalu. Tímto jsme se snažili zajistit vytvoření prostředí s vysokou informací o politických pozicích kandidátů. Potom následovala otázka „Zohlednite-li kandidátovy pozice $v$ daných tématech, jak moc je Vám blízký?"“, kdy možnost odpovědět představovala škála od 0 (není mi vůbec blízký) do 100 (je mi velmi blízký). Na obrazovce s otázkou byla vždy př́tomná fotografie kandidáta, kterého měli participanti hodnotit.

Ve třetí části participanti odpovídali na patnáct otázek zjištujúcích jejich vědomosti o politice pro změření míry jejich politické sofistikovanosti. Na závěr byli požádáni o zhodnocení významu charakteristik, které považují za důležité při volbě kandidáta (mimo 
experimentální prostředí). Na škále od 0 (absolutně nedůležité) do 100 (velmi důležité) hodnotili, jakou důležitost přikládají straně, která kandidáta nominuje, kandidátově minulosti, programu kandidáta, kandidátovým předpokladům pro danou funkci a kandidátově vzhledu a reprezentativnosti.

V experimentu jsme pracovali s mírnou formou decepce, protože kandidáti byli účastníkům sezení představeni jako skuteční (neúspěšní) kandidáti ze senátních voleb. Po skončení sezení následoval debriefing, kde jsme participantům ozřejmili účel a cíl experimentu a zodpověděli jejich dotazy. Z pohledu experimentální etiky lze tento experimentální design vnímat jako neproblematický.

\section{Výsledky}

Cílem následujících stránek textu je prezentace výsledků testování hypotéz formulovaných v teoretické časti článku. Začínáme krátkou deskripcí všech použitých proměnných, poté formulujeme obecný lineární model a testujeme naše hypotézy.

\section{Popis dat}

Základní informace o distribuci čtyř proměnných, které v hlavní analýze figurují ve funkci kontrolních proměnných (Pohlaví, Věk, Znalost politiky, Zájem o politiku), udává Obrázek 5. Jak je z něj patrné, na experimentu participovalo celkem 87 subjektů, z toho 48 žen (55\%) a 39 mužů (45\%), typicky ve věku 21 až 24 let.

Politické znalosti participantů byly testovány patnácti otázkami a počet správných odpovědí dosahoval hodnot mezi 8 a 15. Pro porovnání, subjekt s absolutně žádnou znalostí politiky by zodpověděl správně přibližně pět otázek (protože se jednalo o uzavřené otázky se třemi možnostmi).

Participanti taktéž subjektivně zhodnotili svůj zájem o politiku, a to na škále 0 (absolutní zájem) až 100 (absolutní nezájem). Z pravé dolní části Obrázku 5 vidíme, že distribuce zájmu je rozptýlena po celé škále $0-100$ a že ve vzorku je více subjektů s vysokým deklarovaným zájmem o politiku než subjektů s nízkým deklarovaným zájmem.

Další skupina proměnných se týká pozic subjektů v každém z pěti témat představených výše a významu, který subjekty těmto tématům přiřadily. Pozice subjektů, které byly následně použity pro generování pozic fiktivních kandidátů, zobrazuje levá část Obrázku 6 (přesné znění pozic v Obrázku 2 kódovaných 1-5 je k dispozici v př́loze). Experimentální vzorek není u žádného $\mathrm{z}$ témat př́liš vyhraněný a pozice jsou zastoupeny relativně rovnoměrně. Pravá část obrázku zobrazuje důležitosti, které na škále 0-100 každý ze subjektů přiřadil každému z témat. Vidíme, že se subjekty $\mathrm{v}$ přisuzované důležitosti u každého z témat výrazně lišily. Jako nejdůležitější téma byla typicky označena EU, následována problémovými lokalitami a energetikou. 
Obrázek 5: Popis čtyř kontrolních proměnných

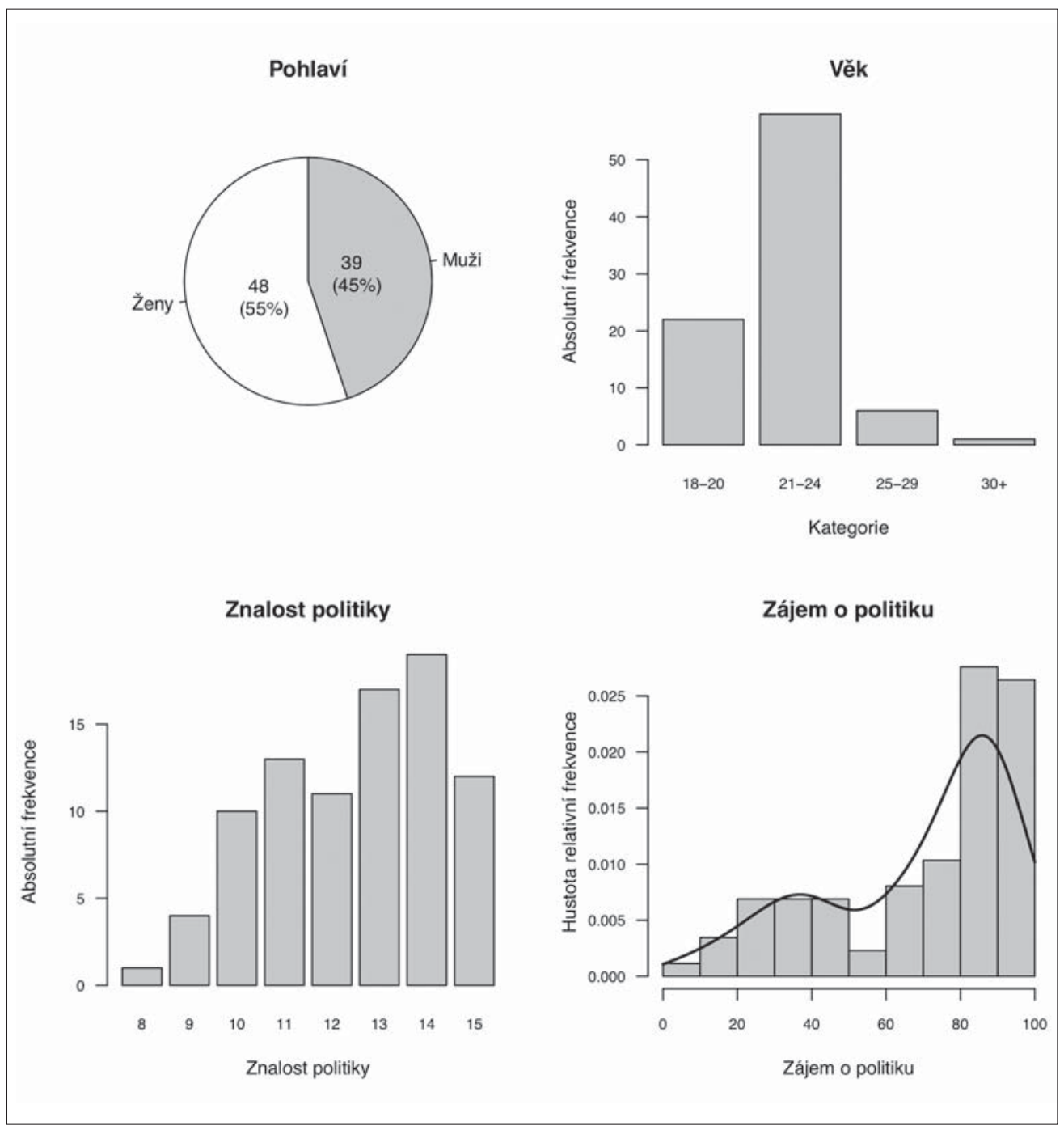

Poznámka: Vertikální osa Hustota relativni frekvence v pravém dolním grafu je konstruována tak, aby se plocha každého z obdélníků histogramu rovnala relativní frekvenci v dané sekci horizontální osy. Křivka proložená histogramem je jádrovým odhadem hustoty pravděpodobnosti a slouží na zjednodušení interpretace histogramu. 
Obrázek 6: Popis pozice subjektů u témat a důležitosti jednotlivých témat

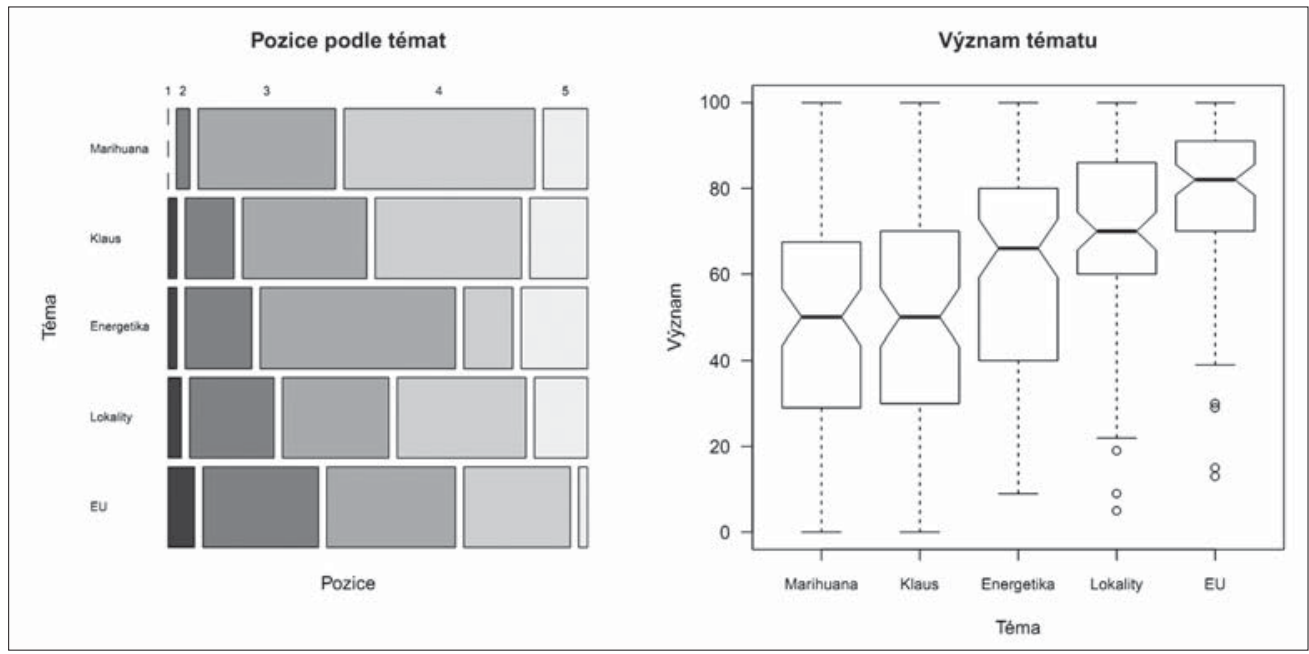

Poznámka: V pravé části Obrázku 6 jsou zobrazeny standardní krabičkové diagramy pro každé z pěti témat. Zářezy na krabičkách sahají do vzdálenosti 1,58 mezikvartilového rozpětí od mediánu a mohou být použity pro přibližné posouzení rozdílu mediánů mezi skupinami na hladině spolehlivosti rovné 95 \% (Chambers a kol. 1983: 62; McGill a kol. 1978: 16). Mozaikový diagram v levé části udává pro každé z témat proporce subjektů v každé z pěti kategorií seřazených od jedné krajní pozice (1) k druhé krajní pozici (5). Popisy každé z pozic jsou k dispozici v př́íloze.

\section{Statistické modelování a testování hypotéz}

Pro testování hypotéz budeme potřebovat indikátory celkové vzdálenosti kandidáta od subjektu a celkového významu, který subjekt v experimentu zastoupeným tématům přiřazuje. Celkovou vzdálenosti subjektu od kandidáta rozumíme součet jejich vzdáleností v každé $\mathrm{z}$ tematických dimenzí, tj.

$$
\text { CelkováVzdálenost }(s, k)=\sum_{d}\left|s_{d}-k_{d}\right|,
$$

kde $s_{d}, k_{d} \in\{1,2,3,4,5\} \quad$ jsou pozice subjektu a kandidáta na dimenzi $d \in\{$ Marihuana,Klaus,Energetika,Lokality, EU\}. Tato operacionalizace předpokládá, že součet vzdáleností v jednotlivých tematických dimenzích je smysluplným reprezentantem celkové vzdálenosti subjektu a kandidáta $\mathrm{v}$ politickém prostoru. I když tento předpoklad není z filozofického hlediska naprosto bezproblémový, v empirických studiích je standardní, a jelikož produkuje robustní operacionalizaci prostorové vzdálenosti, my se k němu také přikláníme. Je také vhodné poznamenat, že závěry naší studie se nezměnily, ani když jsme jako míru vzdálenosti použili jednoduché pořadí kandidátů dle jejich vzdálenosti od subjektu (1 - nejbližšíi, 2 - středně vzdálený, 3 - nejvzdálenější). 
Obrázek 7: Popis konstruovaných proměnných, které měří celkovou vzdálenost kandidátů a celkový význam témat, která byla $\mathrm{v}$ experimentu zahrnuta

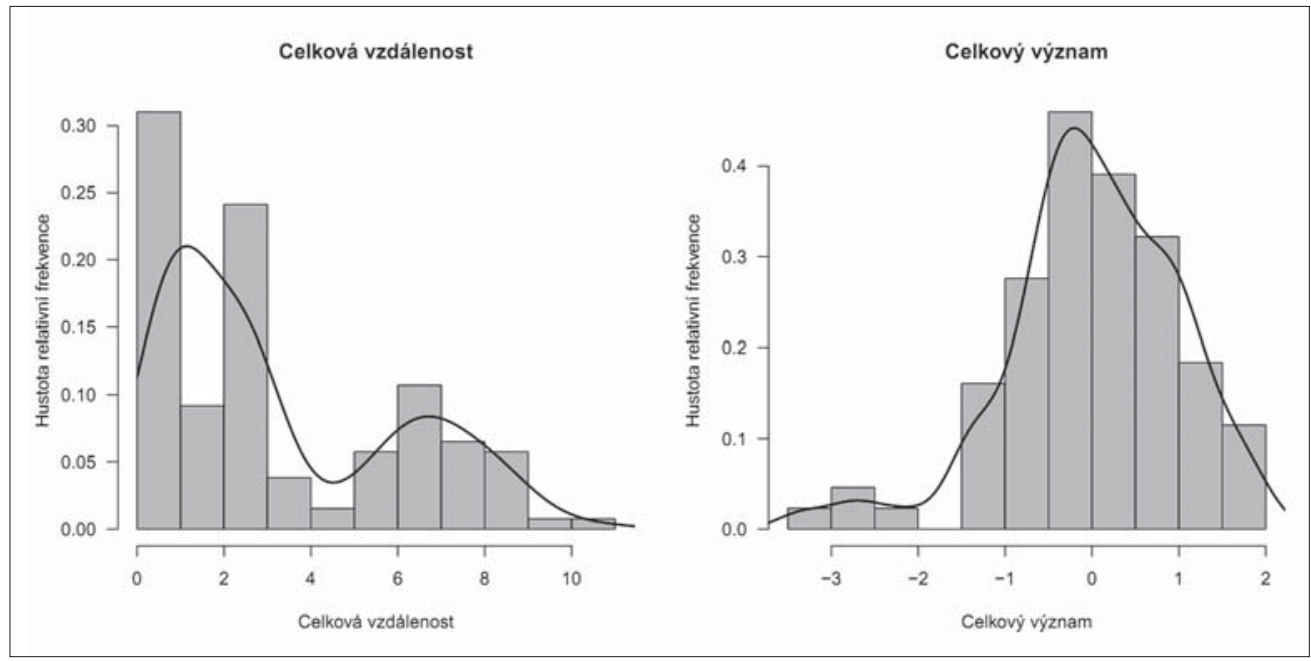

Poznámka: Vertikální osa Hustota relativni frekvence je konstruována tak, aby se plocha každého z obdélníků histogramu rovnala relativní frekvenci v dané sekci horizontální osy. Křivka proložená histogramem je jádrovým odhadem hustoty pravděpodobnosti a slouží na zjednodušení interpretace histogramu.

Celkový význam všech témat pro subjekt definujeme jednoduše jako standardizovaný součet významů, které subjekt přisuzuje každé z dimenzí:

$$
\text { CelkovýVýznam }(s)=\frac{\left(\sum_{d} v_{d}\right)-\bar{v}}{s o_{v}},
$$

kde $\bar{v}$ je průměrná hodnota $\sum_{d} v_{d}$ např́ič všemi subjekty a $s o_{v}$ příslušná standardní odchylka. Standardizování (nebo alespoň vycentrování) tohoto indikátoru je důležité i pro jeho zařazení do lineárního modelu - bez něj by model vykazoval multikolinearitu a znemožňoval validní testování hypotéz.

Distribuce dvou právě zkonstruovaných proměnných zobrazuje Obrázek 7. Jeho levá část jasně odráží tři shluky, které korespondují s celkovou vzdáleností nejbližšího, stř̌edně vzdáleného a nejvzdálenějšího kandidáta. Pravá část Obrázku 7 ukazuje distribuci těžko interpretovatelné, ale pro potřeby testování hypotéz užitečné proměnné celkového významu všech témat. Vidíme, že jeho distribuce je unimodální a jen mírně asymetrická, což podporuje smysluplnost jeho konstrukce. 
Obrázek 8: Popis hodnocení kandidátů

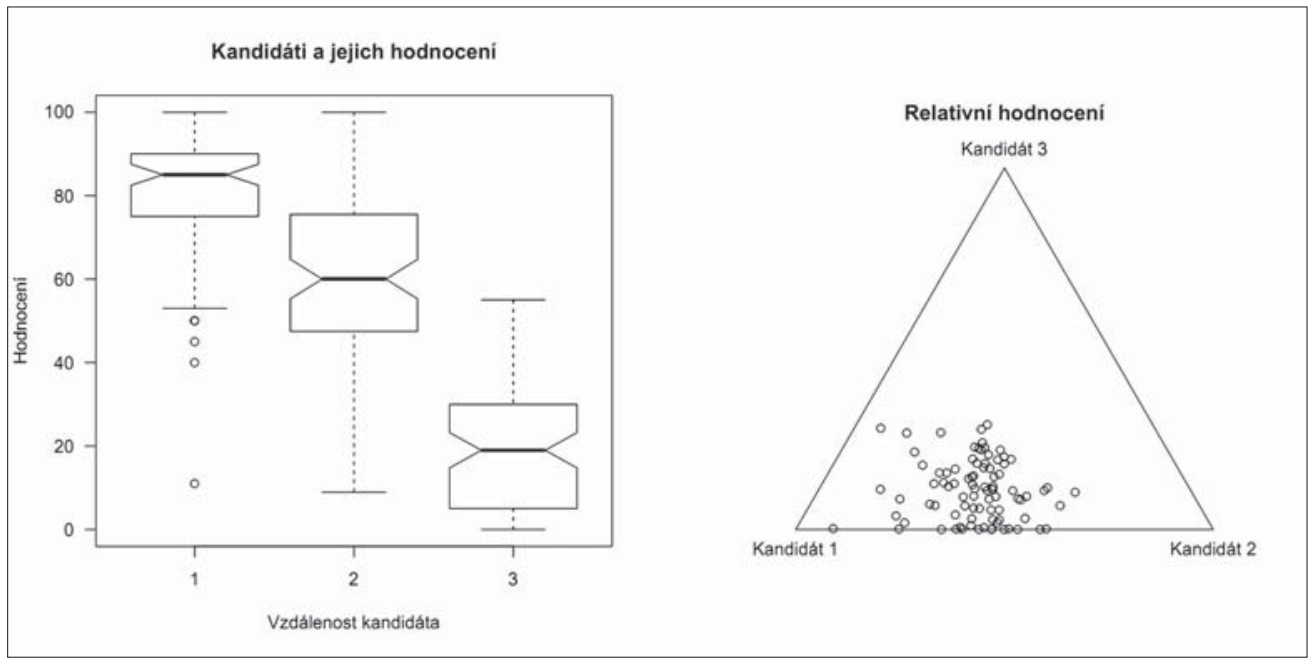

Poznámka: V levé části obrázku jsou zobrazeny standardní krabičkové diagramy pro každé z pěti témat. Zářezy na krabičkách sahají do vzdálenosti 1,58 mezikvartilového rozpětí od mediánu a mohou být použity pro přibližné posouzení rozdílu mediánů mezi skupinami na hladině spolehlivosti rovné $95 \%$ (Chambers a kol. 1983: 62; McGill a kol. 1978: 16). Pravá část obrázku zobrazuje ternární diagram pro hodnocení kandidátů. Pozice každého bodu je určena jeho vzdáleností od stran trojúhelníku; vzdálenost od libovolné strany je proporcionální hodnocení kandidáta umístěného ve vrcholu oproti dané straně.

Nakonec si ještě musíme představit závislou proměnnou, kterou je hodnocení kandidátů subjekty. Obrázek 8 obsahuje informaci o distribuci hodnocení pro nejbližšího, středně vzdáleného a nejvzdálenějšího kandidáta všemi 87 subjekty. Není překvapivé, že vzdálenější kandidáti byli subjekty hodnoceni hůře než bližší kandidáti. Vzdálenost subjektu od kandidáta se tedy jeví být dobrým prediktorem pro jeho hodnocení. V pravé části Obrázku 8 je ternární diagram, který zobrazuje společnou distribuci hodnocení všech tří kandidátů. Hodnocení každého kandidáta je tu zaneseno jako relativní vzhledem k hodnocení ostatních dvou kandidátů daným subjektem (tj. v \%). Pozice každého z 87 bodů je určena jeho vzdáleností od stran trojúhelníku; vzdálenost od libovolné strany je proporcionální hodnocení kandidáta umístněného ve vrcholu oproti dané straně. Z grafu vidíme, že prakticky všech 87 hodnocení spadá do stejné oblasti: daleko od nejvzdálenějšího kandidáta (Kandidát 3) a zároveň o něco blíž k nejbližšímu kandidátovi (Kandidát 1) než ke středně vzdálenému kandidátovi (Kandidát 2).

Jelikož každý z 87 subjektů hodnotil nezávisle tři kandidáty, disponovali jsme celkem $87 \times 3=261$ pozorováními, na jejichž analýzu jsme využili obecný lineární model. Předpokládali jsme, že hodnocení libovolného kandidáta je dáno modelem: 


$$
\begin{gathered}
H=\beta_{0}+\beta_{1} \text { Pohlaví }+\beta_{2} \text { Věk }+\beta_{3} \text { Znalost }+\beta_{4} \text { Zájem }+\beta_{5} \text { CelkováVzdálenost } \\
+\beta_{6} \text { CelkovýVýznam }+\beta_{7} \text { Stereotyp }+\beta_{8} \text { CelkováVzdálenost } \times \text { Stereotyp } \\
+\beta_{9} \text { CelkovýVýznam } \times \text { Stereotyp }+\varepsilon,
\end{gathered}
$$

kde Pohlaví je binární proměnná (Ženy 0 , Muži 1), Věk je zjednodušeně kódován jako kvazi-spojitá proměnná (1 pro kategorii „18-20“ až 4 pro „30+“), proměnné Znalost, Zájem, CelkováVzdálenost a CelkovýVýznam odpovídají jejich definicím výše, Stereotyp je binární proměnná ( 1 pro ,jiného“ kandidáta, 0 pro „neutrálního“ kandidáta) a nakonec standardně $\varepsilon \sim N\left(0, \sigma^{2}\right)$.

Parametry výše uvedeného modelu byly odhadnuty metodou nejmenších čtverců. Diagnostika modelu nevykázala žádné problémy, které by mohly snížit validitu závěrů testování hypotéz na jeho základě. Zároveň má model vysoký koeficient determinace (Tabulka 2), což ukazuje, že dostatečně přesně popisuje závislosti v datech, a můžeme tak na něm založit testovaní našich hypotéz. Individuální p-hodnoty u kontrolních proměnných naznačují, že muži jsou náchylnější hodnotit kandidáty lépe než ženy, a taky že respondenti více se zajímající o politiku hodnotí kandidáty hưře. Vzdálenost kandidáta působí v logickém směru: vzdálenější kandidáti jsou hodnoceni hůře než kandidáti bližší.

Tabulka 2: Výstupy modelu

\begin{tabular}{|l|c|c|c|}
\hline & $\hat{\beta}_{i}$ & $S E\left(\hat{\beta}_{i}\right)$ & p-hodnota \\
\hline Konstanta & 88,07 & 8,86 &. \\
\hline Pohlaví & 6,19 & 2,42 &. \\
\hline Věk & 0,56 & 2,06 &. \\
\hline Znalost & $-0,04$ & 0,71 & $\cdot$ \\
\hline Zájem & $-0,10$ & 0,05 &. \\
\hline CelkováVzdálenost & $-9,64$ & 0,55 &. \\
\hline CelkovýVýznam & 8,35 & 1,51 &. \\
\hline Stereotyp & $-0,62$ & 3,97 &. \\
\hline CelkováVzdálenost×Stereotyp* & 0,53 & 0,94 & $>0,99$ \\
\hline CelkovýVýznam×Stereotyp* & $-3,22$ & 2,60 & 0,65 \\
\hline
\end{tabular}

Poznámka: První sloupec označuje proměnné, druhý sloupec bodový odhad regresních koeficienti̊, třetí sloupec standardní chyby odhadů regresních koeficientů a čtvrtý sloupec p-hodnoty. Jenom regresní koeficienty označené * slouží na testování hypotéz. Tyto p-hodnoty jsou upraveny použitím Holmovy korekce (1979) tak, aby bylo možné testovat současně tři hypotézy. Koeficient determinace $\mathbf{R}^{\mathbf{2}}=\mathbf{0 , 6 4}$.

Jelikož jsme testovali současně tři hypotézy, abychom udrželi pravděpodobnost chyby I. druhu na hladině 0,05 , upravili jsme p-hodnoty všech individuálních testů Holmovou korekcí (1979). Nicméně výsledky by se nezměnily, ani kdybychom použili individuální p-hodnoty. 


\section{Testování hypotézy}

H1: V soutěži se silnou přítomností politických témat nemají stereotypní kritéria vliv na hodnocení kandidáta [Riggle a kol. 1992].

je možné pomocí F-testu sdružené statistické významnosti koeficientů všech tří výrazů, které obsahují proměnnou Stereotyp. Tento test dal hodnotu F statistiky 0,2267 při třech stupních volnosti, což vede k upravené p-hodnotě větší než 0,99 (individuální p-hodnota je 0,88). Předpokládali jsme přitom, že náš experiment skutečně představoval soutěž se silnou přítomností politických témat. Vliv stereotypních kritérií na hodnocení kandidáta v takovéto soutěži se tedy neprokázal.

Hypotézu

H1a: Míra souhlasu s politickými pozicemi kandidátů neovlivňuje ve volbách s vysokou informovaností voličů to, jak jsou voliči ovlivněni stereotypními kritérii při hodnocení kandidátů.

jsme testovali jednoduše pomocí koeficientu $\beta_{8}$, tj. regresního koeficientu při výrazu Celková Vzdálenost $x$ Stereotyp. Jak ukazuje Tabulka 2, př́slušná upravená p-hodnota je prakticky rovná 1, a hypotézu H1a jsme tak zamítnout nemohli. Využívání stereotypních kritérií voliči nezávisí na míře jejich souhlasu s pozicemi kandidátů.

Nakonec, hypotéza

H2: Subjektivní vnímání významu témat v politické soutěži ovlivňuje to, jak jsou voliči ovlivněni stereotypními kritérii při hodnocení kandidátů.

je testovatelná pomocí koeficientu $\beta_{9}$, tj. regresního koeficientu při výrazu CelkovýVýznam $x$ Stereotyp. Tabulka 2 udává př́slušnou p-hodnotu vyšší, než je hladina významnosti $(0,05)$, a proto jsme nemohli H2 podpořit. Nezdá se tedy, že by subjektivní vnímání významu témat mělo vliv na využívání stereotypních kritérií při hodnocení kandidátů.

\section{Diskuse}

Výsledky naší experimentální studie lze v kontextu předchozího výzkumu působnosti stereotypů založených na vzhledu kandidáta považovat za poměrně zajímavé. Řada výzkumů totiž upřednostňuje právě roli vizuálních aspektů kandidáta jakožto klíčový faktor volebního rozhodování voličů na úkor jeho politických pozic (jinými slovy upřednostňují formu před obsahem). My jsme se zaměřili na testování vlivu stereotypů na hodnocení kandidátů v prostředí, kde byl důraz kladen právě na obsahovou složku kandidátovy nabídky. Formální stránka však byla také př́tomna - ve formě fotografie kandidáta. Tento postup přinesl ne zcela obvyklé výsledky - ukázalo se totiž, že role stereotypů není univerzálně platná. V případě tohoto výzkumu se neprokázala role stereotypů spojených s vysokým věkem, obezitou ani cizí etnicitou kandidáta $\mathrm{v}$ hodnocení politických kandidátů. Nejsme však přesvědčeni o tom, že by se jednalo o projev vysoké míry tolerance našich experimentálních subjektů k nestandardním (fyziologickým a fenotypálním) rysům politiků. Naopak se domníváme, že 
jde skutečně spíše o důsledek nastavení našeho experimentálního designu, jehož cílem bylo zkoumat voliče $\mathrm{v}$ momentě, kdy se $\mathrm{v}$ jejich politickém rozhodování do popředí významně prosazují politická témata. Je pozoruhodné, že tento aspekt volby je ve většině dostupné literatury věnující se stereotypům ve volebním rozhodování opomíjen a velká část výzkumné praxe se zaměřuje na podmínku nízké informovanosti voličů, kde politická témata hrají spíše marginální, či dokonce žádnou roli. Naše poznatky jsou tak v souladu s výzkumem Riggle a kol. (1992), podle něhož se s prrítomností ideologie a politických pozic kandidátů zmenšuje prostor pro působení stereotypních rozhodovacích zkratek odvozených od toho, jak kandidáti vypadají.

$\mathrm{V}$ informačně komplexním prostředí, ve kterém mají voliči $\mathrm{k}$ dispozici dobrou informaci o postojích kandidátů, tak nepozorujeme ani vliv vzdálenosti kandidáta od postojů voliče na to, zda je volič ve svém politickém usuzování ovlivňován stereotypy. Tímto se do značné míry odkláníme od poznatků experimentu Schuberta a kol. (2011), kteří vysvětlují zvyšování volitelnosti kandidátů působením vzhledu kandidáta za pomoci asimilačního efektu, kterým voliči v případě standardně vypadajících kandidátů zkreslují politické postoje kandidátů tak, aby byly více $\mathrm{v}$ souladu $\mathrm{s}$ jejich vlastními postoji. Na základě našich dat nelze potvrdit př́tomnost prímých ani nepř́mých vlivů vzhledu kandidáta na míru jeho volitelnosti. Přikláníme se tedy k názoru, že primární funkci základního prvku volebního rozhodnutí plní pozice kandidátů $\mathrm{v}$ jednotlivých politických tématech, jsou-li v politickém prostoru př́tomny, a celková ideová vzdálenost kandidáta od voliče. Přitom ani význam jednotlivých politických témat pro voliče s vlivem stereotypů v politickém rozhodování nesouvisí.

Při formulaci závěrů musíme mít na zřeteli ne zcela nevýznamné limity našeho výzkumu. Vzhledem k experimentálnímu designu lze výše zmíněné výsledky vztahovat pouze k prostředí naší studie a není možné je zobecňovat na celou populaci České republiky. Naše výsledky jsou relevantní především v kontextu teoretických východisek výzkumné problematiky související se stereotypy odvozenými od vzhledu politických kandidátů.

\section{Závěr}

Náš experimentální výzkum vnáší nové téma - a zaplňuje tak pomyslné bílé místo - do studia rozhodování voličů v České republice. Navazujeme prìtom na celou řadu vědeckých poznatků vycházejících zejména z experimentálního výzkumu v USA. To, že je takový postup žádoucí, je nepochybné, vzhledem $\mathrm{k}$ tomu, že právě retestování vědeckých poznatků např́íc různým socio-politickým prostředím může posílit validitu výzkumných závěrů a ukázat, zda se jedná o univerzálně platná teoretická východiska. Přenos výzkumných témat do nových prostředí je přitom vždy do jisté míry problematický, nebot' je nutné výzkum adaptovat na podmínky každého takového prostředí. V našem př́ípadě bylo tedy nutné vzít ohled na podobu českého politického systému, jenž nastavuje určité mantinely volební soutěže. Přitom předpokládáme, že právě $\mathrm{v}$ našich podmínkách je $\mathrm{v}$ rámci volební soutěže klíčová informace o politických postojích, at' již jednotlivých kandidátů nebo politických stran a jejich lídrů obecně. Ačkoliv i v českém politickém prostředí předpokládáme nedokonalou informovanost voličů, jsou právě politická témata stěžejním obsahem volebních kampaní a klíčovým typem informace o jednotlivých politických aktérech. Výsledky této experimentální studie pak ukazují, 
že v prostředí se silnou prrítomností politických témat se prostor pro působení stereotypních zkratek vyvozených ze vzhledu kandidátů výrazně snižuje a nelze jej srovnávat s rolí stereotypů ve volbách s nízkou mírou informací.

\section{Př́loha: Témata a možné pozice $\mathrm{k}$ nim}

Vývoj energetické politiky

Prosím, vyznačte, kterou pozici zastáváte k tématu dalšího vývoje energetické politiky České republiky:

- Vzhledem ke stoupající spotřebě energie se Česká republika neobejde bez jádra ani uhlí. Veškeré investice musí směřovat do těchto tradičních odvětví tak, aby energie z těchto zdrojů pokryla co nejvíce energetickou spotřebu České republiky.

- Jaderná energetika je klíčová pro energetickou soběstačnost ČR. Je nezbytné dobudovat Temelín, Dukovany a do budoucna by bylo výhodné navrhnout nový projekt jaderné elektrárny. Jaderná energie by měla pokrývat většinu vyrobené elektřiny, ostatní zdroje ji mají spíše doplňovat.

- Je žádoucí dokončit výstavbu dvou dalších reaktorů Temelína, a zvýšit tak podíl jaderné energie alespoň na polovinu. Zároveň je třeba investovat do rozvoje obnovitelných zdrojů energie v souladu s evropským cílem zvýšit podíl této energie na 20\% do roku 2020.

- Výstavba jaderných elektráren je drahá a neefektivní. Výstavba nových reaktorů by byla pro Českou republiku ztrátovým projektem. Prostředky by měly být investovány spíše směrem k rozvoji energie z obnovitelných zdrojů.

- Prioritou číslo jedna by měl být rozvoj obnovitelných zdrojů, které jsou jedinou cestou $\mathrm{k}$ energetické soběstačnosti České republiky. Výroba energie z jádra a fosilních paliv má být v budoucnu zcela odbourána.

Směřování Evropské unie

Prosím, vyznačte, kterou pozici zastáváte k tématu dalšího směřování Evropské unie:

- Evropa by měla být maximálně sjednocená, $\mathrm{s}$ jasným záměrem proměny na federaci. Národní státy nemají šanci se ubránit globalizačním tendencím a ekonomické krizi samostatně. Prioritou by mělo být výrazné sjednocení v oblastí daní - korporátních, př́mých i nepřímých. Rozpočty jednotlivých států federace by měly být pod přísným dohledem centra.

- Státy by měly dohodnout své rozpočtové a hospodářské limity, které by EU závazně kontrolovala. Při jejich nesplnění by zemím hrozily sankce. Kompetence EU v oblasti koordinace evropské ekonomiky by měly být posíleny, přičemž korporátní daně by se měly harmonizovat. 
- Proces integrace evropských politik postupuje i přes současnou krizi dobře. Všechny nové návrhy měnící fungování EU by měly být dostatečně projednány a schváleny v referendu v každém členském státě. Každá země by si také měla vybrat, kdy zavede euro. Evropská unie je však stále pro všechny členské státy nejlepším řešením do budoucnosti.

- Evropská unie využívá hospodářské krize jen $\mathrm{k}$ tomu, aby posílila své pravomoci. Místo toho by měl být proveden důkladný audit jejího fungování a její charakter by se měl zcela změnit. Euro jako jednotná měna by se měla zrušit a státy by se měly vrátit $\mathrm{k}$ národním měnám.

- EU by měla být zrušena. V globálním měřítku představuje nekonkurenceschopné společenství, které nás tahá do dluhové spirály. Svými direktivami jen brzdí rozvoj členských zemí. Euro je navíc již mrtvým projektem.

\section{Sociální napětí v ČR}

Prosím, vyznačte, kterou pozici zastáváte k tématu sociálního napětí mezi obyvateli v některých lokalitách České republiky (například Mostecko, Litvínov nebo Šluknovský výběžek):

- Situaci v problémových oblastech není možné donekonečna svádět na slušnou majoritní společnost. Vyřeší ji mnohem lépe represe než jakákoliv prevence.

- Stát musí být jasně schopen rozlišit mezi těmi, kdo se nedostali do problémů vlastní vinou, a těmi, kdo už několikátou generaci odmítají pracovat. Měl by pomáhat jen těm prvním.

- Stát se nesmí vzdávat své role v problémových lokalitách a přispívat v nich ke zmírňování napětí. Musí ale více hlídat efektivitu vynakládání prostředků. Preventivní intervence $\mathrm{v}$ nich je $\mathrm{v}$ současné době často drahá a neúčinná, a navíc vnímaná jako nespravedlivá.

- Situace v problémových lokalitách je důsledkem jejího dlouhodobého neřešení. Stát musí pracovat se všemi skupinami, kterých se problém týká.

- Sociálně vyloučené lokality jsou více než těch, kdo v nich žijí, problémem celé české společnosti. Stát je nyní povinen jejich situaci řešit, zejména prostřednictvím programů prevence sociálních rizik a pomoci sociálně znevýhodněným.

\section{Václav Klaus v roli prezidenta}

Prosím, vyznačte, jaká z následujících pozic hodnotících Václava Klause v roli prezidenta České republiky je Vám nejblíže:

- Václav Klaus je př́kladným prezidentem. Hájí důsledně zájmy České republiky v EU i jinde v zahraničí. Jde o uznávaného odborníka, jehož si ve světě váží. Jeho veřejné působení podporuje v občanech České republiky hrdost a i díky prezidentovi 
nejsou ve společnosti výraznější konflikty. Pokud se takové objeví, má Václav Klaus velký vliv na jejich brzké urovnání.

- Václav Klaus je dobrým prezidentem, který vykonává úřad s patřičnou vážností a autoritou. Jeho prezentace, zejména pak v zahraničí, je sice někdy kontroverzní, většinou ale podporuje zájmy České republiky. Jeho působení ve veřejném prostoru většinou pozitivně působí na občany a urovnává tak konflikty, které zde mohou vznikat.

- Václav Klaus je prezidentem, který České republice nepřináší nic výrazně pozitivního, ale ani ji nijak nepoškozuje. V zahraničí i doma je uznávaným odborníkem, $\mathrm{v}$ některých tématech ale možná zbytečně prezentuje př́liš kontroverzní názory. V takových př́ipadech se může ocitat výjimečně v názorové izolaci.

- Václav Klaus je v mnohém kontroverzní prezident a ne vždy je jasné, zda reprezentuje zájmy České republiky. Nedá se mu upřít, že pro Českou republiku udělal mnoho dobrého, na druhou stranu ale převažují negativa, kdy nevhodně a cíleně provokativně komentuje problémy domácí i zahraniční politiky. Ne vždy tak dokáže národ spojovat.

- Václav Klaus nemá kompetence ani předpoklady k tomu, aby byl českým prezidentem. Poškozuje zájmy České republiky a pouze strhává pozornost na svoji osobu. Důležité je pro něj pouze to, aby se o něm mluvilo, aby byl slyšet jeho hlas, Česká republika a její zájmy jsou pro něj vedlejší. Svými názory a veřejnými vystoupeními doma i v zahraničí jednoznačně polarizuje společnost a přispívá k přítomnosti konfliktů mezi občany.

Legalizace marihuany pro léčebné účely

Prosím, vyznačte, kterou pozici zastáváte k tématu legalizace marihuany pro léčebné účely:

- Marihuana je droga, protože na ní vzniká závislost. V žádném př́padě by neměla být legalizována, a to ani pro léčebné účely.

- Stav výzkumu využití marihuany pro léčebné účely je zatím nedostatečný. Nelze vyloučit závažné vedlejší účinky a rizika. Její využití v medicíně je sice možné, ale zatím předčasné.

- V př́padech, kdy selhává tradiční léčba, jako u Parkinsonovy nemoci, je využití marihuany seriózní možností. Musí však podléhat přísné lékařské kontrole.

- Využití marihuany pro léčebné účely je již běžné v řadě evropských i mimoevropských zemí. Její účinky jsou podpořeny lékařským výzkumem a její legalizace a prodej v lékárnách na lékařský předpis nepředstavuje ani v ČR žádné riziko.

- Marihuana může nahradit řadu jiných léčiv. Její účinky na organismus jsou jednoznačně pozitivní, pomáhá rozvíjet osobnost člověka. Legalizována by měla být všeobecně a stát by ani neměl kontrolovat trh s ní. 


\section{Literatura}

AALBERG, Toril a Anders T. JENSSEN. Gender Stereotyping of Political Candidates. An Experimental Study of Political Communication. Nordicom Review, 2007, roč. 28, č. 1, s. 17-32. ISSN 1403-1108.

ADAMS, John, Lawrence EZROW a Zeynep SOMER-TOPCU. Is Anybody Listening? Evidence That Voters Do Not Respond to European Parties' Policy Statements During Elections. American Journal of Political Science, 2011, roč. 55, č. 2, s. 370-382. ISSN 1540-5907.

ALVAREZ, Michael R. Issues and Information in Presidential Elections. Ann Arbor: University of Michigan Press, 1997. ISBN 0472022377.

ALVAREZ, Michael R. a John BREHM. Hard Choices, Easy Answers: Values, Information, and American Public Opinion. Princeton: Princeton University Press, 2002. ISBN 069109635X.

ALVAREZ, Michael R. a Charles H. FRANKLIN. Uncertainty and Political Perceptions. Journal of Politics, 1994, roč. 56, č. 3, s. 671-688. ISSN 1468-2508.

BANDUCCI, Susan A., Michael TRASHER, Colin RALLINGS a Jeffrey A. KARP. Candidate Appearance Cues in Low-Information Elections. Annual Meeting of the American Political Science Association. 28.-31. srpna 2003, Philadelphia (PA): American Political Science Association.

BARRETT, Andrew W. a Lowell W. BARRINGTON. Is a Picture Worth a Thousand Words? Newspaper Photographs and Voter Evaluations of Political Candidates. The Harvard International Journal of Press/Politics, 2005, roč. 10, č. 4, s. 98-113. ISSN 1940-1612.

BERNARD, Josef. Individuální charakteristiky kandidátů ve volbách do zastupitelstev obcí a jejich vliv na volební výsledky. Sociologický časopis, 2012, roč. 48, č. 4, s. 613-640. ISSN 0038-0288.

BERTRAND, Marianne, Dolly CHUGH a Sendhil MULLAINATHAN. Implicit discrimination. American Economic Review, 2005, roč. 95, č. 2, s. 94-98. ISSN 0002-8282.

CASTILLO, Marco a Ragan PETRIE. Discrimination in the lab: Does information trump appearance? Games and Economic Behavior, 2010, roč. 68, č. 1, s. 50-59. ISSN 0899-8256.

DRUCKMAN, James N. The Power of Television Images: The First Kennedy-Nixon Debate Revisited. The Journal of Politics, 2003, roč. 65, č. 2, s. 559-571. ISSN 1467-9760.

ENELOW, James M. a Melvin T. HINICH. The spatial theory of voting: An introduction. New York: Cambridge University Press, 1984. ISBN 0521275156.

FERSHTMAN, Chaim, Uri GNEEZY a Frank VERBOVEN. Discrimination and Nepotism: The Efficiency of the Anonymity Rule. The Journal of Legal Studies, 2005, roč. 34, č. 2, s. 371-396. ISSN 0047-2530.

GILLIAM, Franklin D. a Shanto IYENGAR. Prime Suspects: The Influence of Local Television News on the Viewing Public. American Journal of Political Science, 2000, roč. 44, č. 3, s. 560-573. ISSN 1540-5907.

GORDON, Ann, David M. SHAFIE a Ann N. CRIGLER. Is Negative Advertising Effective for Female Candidates? An Experiment in Voters' Uses of Gender Stereotypes. Harvard International Journal of Press/Politics, 2003, roč. 8, č. 3, s. 35-53. ISSN 1940-1612.

GRABER, Doris A. Kind Words and Harsh Pictures: How Television Presents the Candidates. In SCHLOZMAN, Kay L. (ed.). Elections in America. Boston: Allen \& Unwin, 1987, s. 115-141. ISBN 0044970234.

GRABER, Doris A. Seeing Is Remembering: How Visuals Contribute to Learning from Television News. Journal of Communication, 1990, roč. 40, č. 3, s. 134-155. ISSN 1460-2466.

HENRY, Brady a Paul SNIDERMAN. Attitude Attribution: A Group Basis for Political Reasoning. American Political Science Review, 1985, roč. 79, č. 4, s. 1061-1078. ISSN 0003-0554. 
HOLM, Sture. A simple sequentially rejective multiple test procedure. Scandinavian Journal of Statistics, 1979, roč. 6, č. 2, s. 65-70. ISSN 03036898.

HUDDY, Leonie a Nayda TERKILDSEN. Gender Stereotypes and Perceptions of Male and Female Candidates. American Journal of Political Science, 1993, roč. 37, č. 1, s. 119-147. ISSN 1540-5907.

CHAMBERS, John M., William S. CLEVELAND, Beat KLEINER a Paul A. TUKEY. Graphical Methods for Data Analysis. New Jersey: Wadsworth \& Brooks/Cole, 1983. ISBN 053498052X.

IYENGAR, Shanto, Nicholas VALENTINO, Stephen ANSOLABEHERE a Adam SIMON. Running as a Woman: Gender Stereotyping in Women's Campaigns. In NORRIS, Pippa (ed.). Women, Media, and Politics. New York: Oxford University Press, 1997, s. 77-98. ISBN 0195105672.

KAHN, Kim F. Gender Differences in Campaign Messages: The Political Advertisements of Men and Women Candidates for U. S. Senate. Political Research Quarterly, 1993, roč. 46, č. 3, s. 481-502. ISSN 1065-9129.

KAHN, Kim F. The Political Consequences of Being a Woman. New York: Columbia University Press, 1996. ISBN 0231103034.

LAU, Richard a David REDLAWSK. Advantages and Disadvantages of Cognitive Heuristics in Political Decision Making. American Journal of Political Science, 2001, roč. 45, č. 4, s. 951-971. ISSN 1540-5907.

LEFEVERE, Jonas. Campaign Effects on Voter Decision Making. 2011. Disertační práce. Universiteit Antwerpen.

LUPIA, Arthur. Shortcuts versus encyclopedias: Information and voting behavior in California insurance reform elections. American Political Science Review, 1994, roč. 88, č. 1, s. 63-76. ISSN 0003-0554.

MALÁ, Ivana. Jaký má být nový český prezident? Brno, 2013. Diplomová práce. Fakulta sociálních studií Masarykovy univerzity.

MATLAND, Richard E. Putting Scandinavian Equality to the Test: An Experimental Evaluation of Gender Stereotyping of Political Candidates in a Sample of Norwegian Voters. British Journal of Political Science, 1994, roč. 24, č. 2, s. 273-292. ISSN 0007-1234.

MATSUBAYASHI, Tetsuya a Michiko UEDA. Political Knowledge and the Use of Candidate Race as a Voting Cue. American Politics Research, 2011, roč. 39, č. 2, s. 380-413. ISSN 1532-673X.

MATTES, Kyle, Michael SPEZIO, Hackjin KIM, Alexander TODOROV, Ralph ADOLPHS a R. Michael ALVAREZ. Predicting Election Outcomes from Positive and Negative Trait Assessments of the Candidate Images. Political Psychology, 2010, roč. 31, č. 1, s. 41-58. ISSN ISSN 0162-895X.

McGILL, Robert, John W. TUKEY a Wayne A. LARSEN. Variationsof box plots. The American Statistician, 1978, roč. 32, č. 1, s. 12-16. ISSN 00031305.

McGRAW, Kathleen. Contributions of the Cognitive Approach to Political Psychology. Political Psycho$\log y, 2000$, roč. 21, č. 4, s. 805-832. ISSN 0162-895X.

MEHRABIAN, Albert. Silent Messages. Belmont: Wadsworth, 1971. ISBN 0534000592.

MEYER, Thomas M. Constraints on Party Policy Change. Essex: ECPR Press, 2013. ISBN 1907301496.

MILLER, Beth J. a Jennifer D. LUNDGREN. An experimental study of the role of weight bias in candidate evaluation. Obesity, 2010, roč. 18, č. 4, s. 712-718. ISSN 1930-739X.

NISBETT, Richard E. a Lee ROSS. Human Inference: Strategies and Shortcomings of Social Judgment. Englewood Cliffs: Prentice Hall, 1980. ISBN 0134451309.

O'BRIEN, Kerry S., Janet D. LATNER, Daria S. EBNETER a John A. HUNTER. Obesity discrimination: the role of physical appearance, personal ideology, and anti-fat prejudice. International Journal of Obesity, 2012, s. 1-6. ISSN 0307-0565.

PALVIO, Allan. Images in Mind: The Evolution of a Theory. New York: Harvester Wheatsheaf, 1991. ISBN 0745009387.

POPKIN, Samuel L. The Reasoning Voter: Communication and Persuasion in Presidential Campaigns. Chicago: University of Chicago Press, 1991. ISBN 0226675440. 
RIGGLE, Ellen D, Victor C. OTTATI, Robert S. WYER, James KUKLINSKI a Norbert SCHWARZ. Bases of Political Judgments: The Role of Stereotypic and Nonstereotypic Information. Political Behavior, 1992, roč. 14, č. 1, s. 67-87. ISSN0190-9320.

RÖDIN, Magnus a Gülay ÖZCAN. Is It How You Look or Speak That Matters? - An Experimental Study Exploring the Mechanisms of Ethnic Discrimination. Research Papers in Economics, 2011, č. 12, Stockholm University, Department of Economics.

ROSENBERG, Shawn, Lisa BOHAN, Patrick McCAFFERTY a Kevin HARRIS. The Image and the Vote: The Effect of Candidate Presentation on Voter Preference. American Journal of Political Science, 1986, roč. 30, č. 1, s. 108-127. ISSN 1540-5907.

SÁNCHEZ-CUENCA, Ignaci. How Can Governments Be Accountable if Voters Vote Ideologically? In MARAVALL, José M. a Ignacio SÁNCHEZ-CUENCA (eds.). Controlling Governments: Voters, Institutions, and Accountability. Cambridge: Cambridge University Press, 2007, s. 45-81. ISBN 052171110X.

SAPIRO, Virginia. If Senator Baker Were a Woman: An Experimental Study of Candidate Images. Political Psychology, 1982, roč. 2, č. 1, s. 61-83. ISSN 1467-9221.

SCHUBERT, James N., Margaret A. CURRAN a Carmen STRUNGARU. Physical attractiveness, issue agreement, and assimilation effects in candidate appraisal. Politics and Life Sciences, 2011, roč. 30, č. 1, s. 33-49. ISSN 0730-9384.

SIGELMAN, Lee, Carol K. SIGELMAN. Sexism, Racism, and Ageism in Voting Behavior: An Experimental Analysis. Social Psychology Quarterly, 1982, roč. 45, č. 4, s. 263-269. ISSN 1939-8999.

SIGELMAN, Lee, Carol K. SIGELMAN a Christopher FOWLER. A Bird of a Different Feather? An Experimental Investigation of Physical Attractiveness and the Electability of Female Candidates. Social Psychology Quarterly, 1987, roč. 50, č. 1, s. 32-43. ISSN: 1939-8999.

SNIDERMAN, Paul M., Richard A. BRODY a Phillip E. TETLOCK. Reasoning and Choice: Explorations in Political Psychology. Cambridge: Cambridge University Press, 1991. ISBN 0521407702.

TODOROV, Alexander, Anesu N. MANDISODZA, Amir GOREN a Crystal C. HALL. Inferences of Competence from Faces Predict Election Outcomes. Science, 2005, roč. 308, č. 10, s. 1623-1626. ISSN 1095-9203.

WYER, Richard S., Thomas L. BUDESHEIM, Sharon SHAVITT, Ellen D. RIGGLE, Jeffrey R. MELTON a James H. KUKLINSKI. Images, Issues and Ideology: The Processing of Information about Political Candidates. Journal of Personality and Social Psychology, 1991, roč. 61, č. 4, s. 535-545. ISSN1939-1315.

\section{Autorský tým}

Roman Chytilek je odborným asistentem na Katedře politologie Fakulty sociálních studií Masarykovy univerzity a výzkumným pracovníkem v Mezinárodním politologickém ústavu na téže fakultě. Jeho odborným zájmem jsou volby a experimentální politologie. V současné době je řešitelem projektu, v němž se zabývá zkoumáním volebního chování a rozhodování ve vysoce personalizovaných volbách.

Kontakt: chytilek@fss.muni.cz

Otto Eibl je odborným asistentem na Katedře politologie Fakulty sociálních studií Masarykovy univerzity a výzkumným pracovníkem v Mezinárodním politologickém ústavu na téže fakultě. Odborně se zaměřuje na výzkum otázek spojených zejména s politickým marketingem, popř. politickou komunikací.

Kontakt: eibl@fsss.muni.cz 
Lenka Hrbková působí jako výzkumná pracovnice v rámci Mezinárodního politologického ústavu a studuje doktorské studium na Katedře politologie Fakulty sociálních studií Masarykovy univerzity. $Z$ odborného hlediska se zabývá především tématy politické psychologie, jako jsou politické rozhodování, emoce a kognice v politice a politické postoje. Kontakt: hrbkova.len@gmail.com

Jozef Zagrapan je doktorand na Katedře politologie Fakulty sociálních studií Masarykovy univerzity. Výzkumně se věnuje zejména experimentální politologii a působení politických stran na internetu.

Kontakt: zagrapan@fss.muni.cz

Jozef Janovský působí jako výzkumný pracovník na Katedře mezinárodního a evropského práva Právnické fakulty Masarykovy univerzity. Jako statistik se rovněž zapojuje do experimentálního výzkumu v Mezinárodním politologickém ústavu Fakulty sociálních studií Masarykovy univerzity.

Kontakt: janovsky@mail.muni.cz 